\title{
Electro-sequence analysis and natural resources potential of a transitional environment in central swamp depobelt, Niger delta, Nigeria
}

\author{
Emmanuel I. Akaerue ${ }^{1}$ (D) Joseph N. Nnakuba ${ }^{2}$. Job G. Urang ${ }^{1}$ · Ebong D. Ebong ${ }^{1}$ · Joseph N. Eradiri ${ }^{2}$. \\ Anthony N. Ugbaja ${ }^{3}$
}

Received: 3 June 2021 / Accepted: 19 September 2021 / Published online: 15 February 2022

(c) The Author(s) 2022

\begin{abstract}
Sequence stratigraphy and Electrosequence of the Don-Field Central Swamp depobelt of the Niger Delta Basin, was carried out using well logs, biostratigraphic and core data. The aim of this study is to re-characterise and revalidate the reservoirs within the study area and provide an optimum framework for predicting reservoir character, development and reservoir quality distribution. Detailed petrophysical evaluation reveals proficient hydrocarbon reservoir units with variable parameters (i.e. porosity, permeability and shale volume) that can accommodate productive hydrocarbon reserve. Core data analyses revealed heavy minerals like pyrites and glauconites that can be of economic interest. The gamma wireline signatures of the wells show reservoir units that are predominantly blocky in shape indicative of fluvial channels. Fluvial channels are typically associated with coastal and/or marginal marine environments. More so, the aforementioned observations were validated using palaeoenvironmental interpretation of strata penetrated by Well-1, Well-2, and Well-3 via the sidewall core analyses. Sequence stratigraphic surfaces such as maximum flooding surfaces (MFS) and sequence boundary (SB) were observed to show good correlation with palynological and foraminiferal zones. The stacking patterns (i.e. progradation, retrogradation and aggradation) encountered gave acumen into systems tracts (i.e. lowstand system tract (LST), transgressive system tract (TST) and highstand system tract (HST) interpretation. These system tracts constitute a depositional sequence set of middle-late Miocene age bounded chronologically by MFS of 9.5 Ma, 12.8 Ma, 15.0 Ma, 15.9 Ma and SB of 12.1 Ma, 13.1 Ma, 15.5 Ma, 15.9 Ma. The SB and MFS were delineated based on Shell Petroleum Development Company (SPDC) biozonation scheme: F-zone and P-zone were within P820-P680 and F9500-F9600/F9700 as contained in the biofacies interpreted data of index fossils (Globorotalia foshi S.I; Globorotalia praefohsi; Globorotalia peripheroacuta; Orbulina spp; Praeorbulina sicana; Paragloborotalia mayeri; Neogloboquadrina acostaensis) which corresponded to the alphanumeric code N8-N16 planktonic foraminiferal zones of Blow.
\end{abstract}

Keywords Depositional system $\cdot$ Biostratigraphic markers $\cdot$ Electrosequence $\cdot$ Formation evaluation $\cdot$ Niger delta

\section{Introduction}

Emmanuel I. Akaerue

emmanuelakaerue@unical.edu.ng

1 Applied Geophysics Programme, Physics Department, University of Calabar, PMB 1115, Calabar, Cross River State, Nigeria

2 Department of Geology, Faculty of Physical Science, University of Nigeria, Nsukka, Nigeria

3 Department of Geology, Faculty of Physical Science, University of Calabar, Calabar, Nigeria
Over the years, the global demand for oil and gas products has continued to increase and this situation has intensified exploration activities in search for new hydrocarbon reserves. Based on the aforementioned reasons, the Niger Delta Basin has been extensively studied to unravel subtle stratigraphic and structural traps (Knox and Omatsola 1987; Weber and Daukoru 1975; Evamy et al. 1978; Ejedawe 1981; Urang et al. 2020). In order to meet the increased global demand for oil and gas, different geological, geophysical and geochemical approaches have been employed in hydrocarbon exploration and exploitation. However, these 
methods tend to be complex, expensive, and pose enormous challenge during formation evaluation and decision-making (Ladipo 1992; Stacher 1995). Concurrently, it is important to take into account the risks associated with the environment, economy and technology uncertainties during oil and gas exploration. Formation evaluation provides maximum framework for reservoir assessment geared towards successful exploration, development and exploitation of commercially viable hydrocarbon reservoirs. The sedimentological and stratigraphic facets of Africa's leading oil province have been opened-up in recent time by the works of Reijer (2011) and Mode et al. (2015) based on the pioneer researches of Short and Stauble (1967), Weber (1971), Knox and Omatsola (1987), Ladipo (1992), Stacher (1995) and Durand (1995). Previous research works on sedimentological, biostratigraphic and sequence-stratigraphic styles clarified the collective influence of eustatic cyclicity and local tectonics (Ladipo 1992; Stacher 1995; Reijers et al. 1997; Owoyemi and Willis 2006; Magbagbeoloa and Willis 2007; Anyiam et al., 2019). Thus, the genetic sequence of depositional belt is marked at the top by the maximum flooding surface and at the base by a transgressive surface. Galloway (1989a, b), based on reports of Frazier (1974) proposed that maximum flooding surfaces rather than sub-aerial unconformities be used as sequence boundaries. Thus, strata bounded by maximum flooding surfaces within transgressive shales are more readily identifiable in the Niger Delta. Individual sea-level cycles are reflected in the Niger Delta in various sedimentary sequences (Haq et al. 1988). Interferences of these cycles with different periods resulted in the formation of sequence sets that are chronostratigraphically confined and sedimentologically characterised. The aim of this study is to reflect, revalidate and establish a cost effective way by which sequence sets can provide optimum framework for predicting reservoir character and quality distribution in the central swamp depobelt, Niger Delta-Nigeria.

\section{Location and geology of the study area}

The study area is part of the Cenozoic oil prolific Niger Delta Basin according to Merki (1972). The area "Donfield" is located in the Central Swamp Depobelt of the Niger Delta within Oil Mining Lease-12 (OML-12) block with an area of about $91,803.278$ square feet. It is located between Longitudes $7^{\circ} 0.22^{\mathrm{I}} \mathrm{E}-7^{\circ} 0.32^{\mathrm{I}} \mathrm{E}$ and Latitudes $4^{\circ} 0.81^{\mathrm{I}}$ $\mathrm{N}-4^{\circ} 0.85^{\mathrm{I}} \mathrm{N}$ (Fig. 1).

The Niger Delta is a terrigenous epicratonic embayment which lies at the edge of the Africa continental crust (Weber and Daukoru 1975; Evamy et al. 1978; Ejedawe 1981). The sedimentary basin is composed of five depositional units known as depobelts that are considered as separate entities based on the diversity in stratigraphic, structural framework and hydrocarbon distribution (Hospers 1965; Stoneley 1966; Burke et al. 1972; Doust 1987; Knox and Omatsola 1989). These depobelts are: (i) the Northern Delta of Late Eocene-Middle Miocene, (ii) Greater Ughelli of Oligocene-Early Miocene, (iii) Central Swamp of Middle-Late Miocene, (iv) Coastal Swamp of Late Miocene-Pliocene and (v) Offshore of Middle- Late Pliocene (Weber 1971; Weber and Daukoru 1975; Doust and Omatsola 1990). The deltaic deposit are composed predominantly of regressive clastic successions mainly of sedimentary origin and this regressive packages consists of deltaic deposits that are defined by three main lithostratigraphic units, i.e. Akata, Agbada and Benin formations (Fig. 2). The marine shales of the Akata formation at the base consist mainly of overpressured marine shales that are about 19,685.04 feet thick. The Akata formation is overlain by the Agbada formation that is composed of paralic successions of interbedded sands and shales, about $13,123.36$ feet thick in the central parts, but however, thins seawards andtowards the delta margin. The non-marine alluvial continental depositsof the Benin formation is composed mainly of fluviatile gravels and sands that thickens up to 6561.68 feet in the delta centre and thins towards the delta margin. The Niger Delta basin currently produces hydrocarbons mainly from rocks of Eocene-Pliocene age, (Weber and Daukoru 1975; Evamy et al. 1978; Ekweozor and Daukoru 1994; Ekweozor and Okoye 1980; Haack et al. 2000). However, due to the advancement in exploration technology, investigation in the basin is gradually shifting to the delta toe and flanks of the delta, where Cretaceous prospects are expected.

\section{Materials and methods}

Formation evaluation, involves the estimation of lithological properties, reservoir potential and performance based on parameters such as porosity, permeability, grain size, degree of compaction, paleoenvironmental indices, amount of matrix and cement components. The aforementioned parameters were determined through analysis of wireline log suites, sidewall core samples and biostratigraphics data. The flow chart of the methodology is as presented in Fig. 3.

\section{Extraction of petrophysical parameters from wireline logs}

The well log data from Don-Field was made available for research by Shell Petroleum Development Company, Nigeria. An indispensable step in formation evaluation procedure is the estimation of amount of shale present in the prospective sandstone. (Ulasi et al. 2012; Urang et al. 2020). This aided the exact estimation of formation porosity and fluid content contained within the pay zone. Wireline logs were 


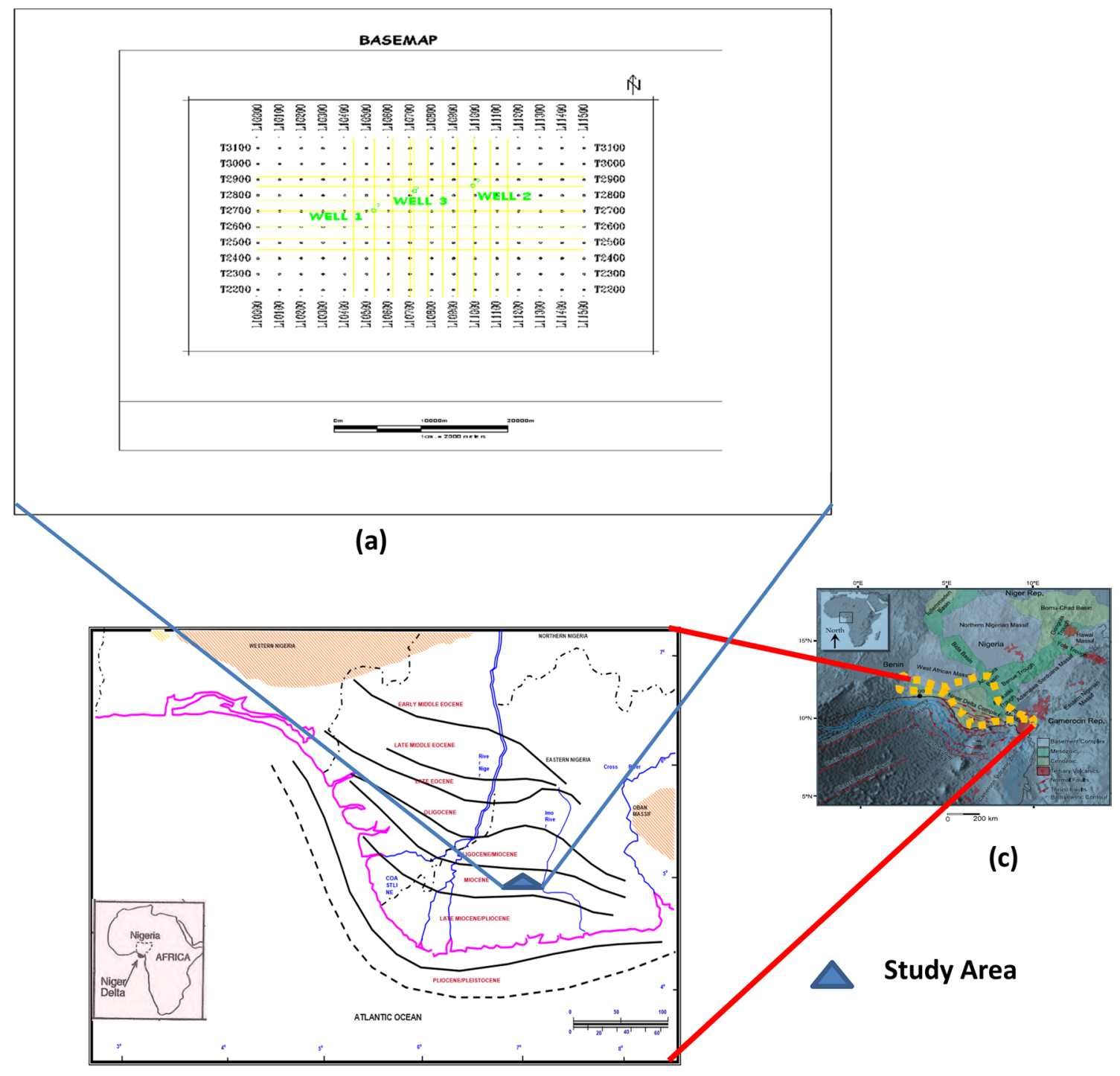

(b)

Fig. 1 a Base map of the Don-field, central depobelt, Niger delta b Niger delta basin and its stage development.adapted from Short and Stauble, 1967 c Regional basins map of Nigeria showing Niger delta (Adapted from Corredor et.al., 2005)

used to ascertain depths of deposition, thickness of hydrocarbon productive intervals, specific reservoir parameters and to distinguish between fluids in the reservoir encountered using derivative models of Archie's Eqs. (1942) Suites of wireline logs ranging from gamma ray (GR), resistivity (LLD), sonic (DT), density (RHOB) and neutron (NPHI) logs were used in this study. This study considers the case of tertiary unconsolidated siliciclastic rocks where composition, pore geometry, interbedded thin shale layers, effect of invasion, pore fluid types and saturation levels, fluids distribution pattern, cracks and their orientation, grain packing, pore networks are possible sources of confidence in quantitative reservoir parameter evaluation. Owning to the aforementioned effectiveness in petrophysical evaluation their significance can sway or converse depending upon the area, geology, compaction and depositional environment. Volume of shale (Vsh) is calculated and estimated through gamma ray index (IGR) from GR log to approximate clay contents in the reservoir rock using Larionov Eqs. (1969). The porosity of the reservoir interval is calculated and corrected by using density and neutron logs derivatives. The water saturation within reservoir pores was estimated from resistivity log using Archie's Eq. (1942) for clean sand intervals. The hydrocarbon saturation (Sh) (the percentage 


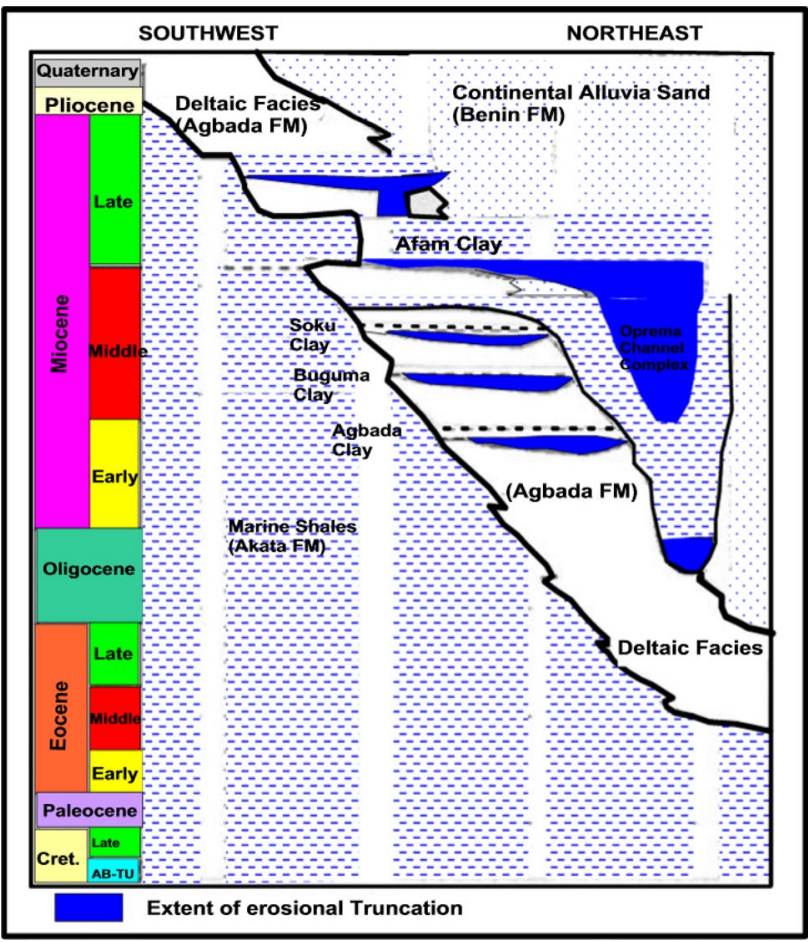

Fig. 2 Stratigraphic column showing the three formations of the Niger Delta (Modified from Owoyemi 2004)

of pore volume in a formation occupied by hydrocarbons) was obtained by subtracting the value obtained for water saturation from $100 \%$. The permeability, $(\mathrm{K})$ (which is the ability of a rock to transmit fluid) was calculated by Wyllie and Rose (1950) log derived permeability equation. The ratio of water saturation to flushed zone water saturation gives the amount of hydrocarbons which have been moved by the invasion process. This ratio inferred as the moveable hydrocarbon index (MHI). Similarly, the work by Akaerue, et. al. (2018) in the same study area gave comprehensive mathematical derivatives and equations which were used in the current work to compute the petrophysical parameters. Gamma ray log was used to delineate different lithologies. The qualitative identification of reservoir zones was done using the log signatures from the studied packages. Strata with high GR, high neutron values, low resistivity and low density values indicated shale and was thus eliminated. Well log patterns of the sedimentary facies were then identified and interpreted through the gamma ray and resistivity log motifs in conjunction with biofacies interpretation, consequently providing information on rock properties and depositional environment as modelled by Busch (1975), Schlumberger (1985), Mode et al. (2015) and Anyiam, et al. (2019) (Fig. 4a, b).

\section{Core data}

Core data are usually generated during or after drilling operations, especially from exploration or production wells for the purpose of obtaining different information related to subsurface geology (Keelan 1982). This provided information on the physical rock properties and facies analysis (lithology, porosity and fluid evaluation). The rock fabric and degree of compaction were considered as these affect porosity and permeability which are fundamental properties of the reservoir in determining quality and effectiveness. Shale volume was also estimated from the core analysis. Paleoenvironment of deposition of the rock and reservoir quality were determined to complement wireline log signatures. Total 65 core sidewall samples were taken in the interval of 4446 feetto 10,110 feetand analysed to measure uncertainty in petrophysical and rock physics parameters. Proper sedimentological analysis was carried out to ascertain the degree of heterogeneity in the sandstones as this could greatly affect quality.

\section{Biostratigraphic reports}

Biostratigraphic analysis of fossil material derived from core and cuttings delivers information on the age of sediments, the correlation surfaces between wells, and the depositional environment. The biostratigraphic data supplied by SPDC Nigeria Limited of Well-1 and Well-2 were used for the reservoir characterisation (Tables 1, 2, 3 and 4). A total of 105 composited samples from depth of 3340 to 9855 feet and 3700 to 10,640 feet, respectively, were processed and analysed for micropaleontological and palynological studies. Interpreted palynological $(\mathrm{P})$ zone and Foraminifera $(\mathrm{F})$ zone based on SPDC bio-zonation scheme were calibrated and depth matched with corresponding wireline logs. The population and diversity of the benthic and planktonic foraminifera integrated with the wireline motifs were used for the stratigraphic surfaces interpretation and ages assigned. (Fig. 4b, 5, 6).

\section{Results and discussion}

\section{Petrophysical analysis of Well-1 reservoirs}

By applying a cutoff value of 70.1 API for the GR log, five reservoir units were delineated in Well-1 within the Agbada formation. The five reservoir units, i.e. A1 to A5 have thicknesses of 320,160, 190, 52 and 25 feet, respectively (Table 5).The thickness of the individual net sand units ranged from 15 to 110 feet indicating that these reservoirs are not completely clean but contain some inter-fingerings of shale (a typical characteristic of paralic succession such as the Agbada formation). Average porosity values in the 


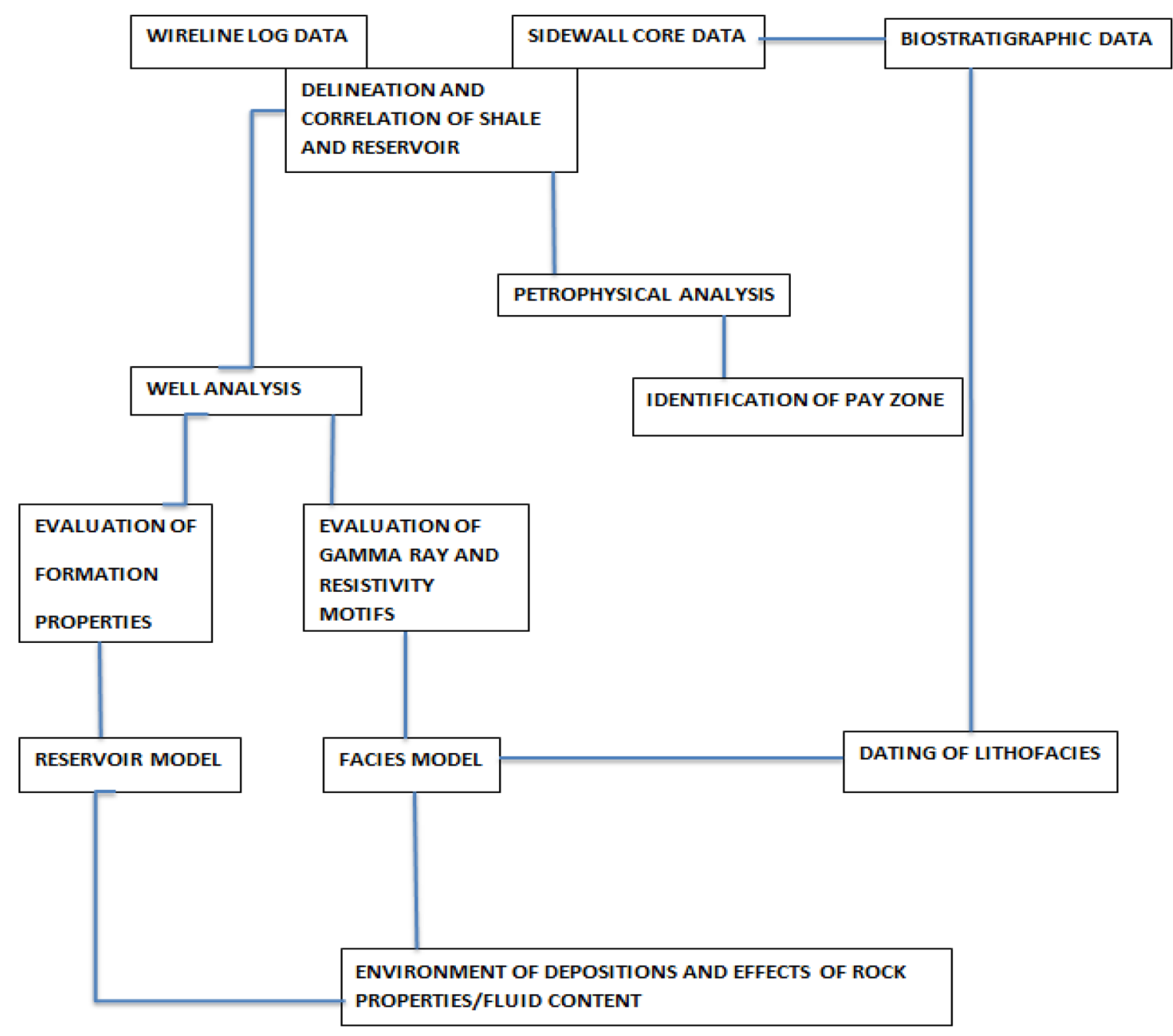

Fig. 3 Work flow chart

reservoirs range from 16.07 to $21.51 \%$ suggesting, good to very good porosity reservoirs for the well (Rider 1986; Etuefeotor 1997). The average volume of shale (Vsh) in reservoir A1 is $5.37 \%$ suggesting clean sand reservoir (Davies 2002). This means that the average volume of shale (Vsh) value in reservoir A1 may not affect its water saturation (Sw) significantly, unlike in other reservoirs (A2 to A5) where average volume of shale was more than 10 to $15 \%$ which is the permitted threshold according to Hilchie, (1978). Average resistivity and permeability values of 26.54 and 33.87 ohms-metre, and 131.08 and 1920.22 md, respectively, of reservoirs A5 and A3 suggested that these reservoir units contain hydrocarbon with excellent permeability. Reservoirs A1, A2 and A4 have average resistivity values of 1.5, 1.96 and $1.14 \Omega \mathrm{m}$, respectively. This suggests that the fluid within the reservoirs may be formation water. Also, these reservoirs have average water saturation percentage values of 79.41, 30.12 and $40.6 \%$, respectively. Hence, suggesting high water saturation zones with little or no hydrocarbon.

\section{Petrophysical analysis of Well-2 reservoirs}

Well-2 is located at the eastern part of the 'Don Field'. A cutoff value of 69.0 API for the GR log was used to differentiate reservoirs from non-reservoirs. The reservoirs identified in Well-2 (B1 to B7), ranged in thickness from 30 feet in reservoirs B1 to 269 feet in B3 (Table 6). Reservoirs have very good to excellent average porosity values which ranges from $20.71 \%$ in reservoir B 7 to $22.97 \%$ in reservoir $\mathrm{B} 2$. Reduction in average porosity values from reservoirs B1 
a

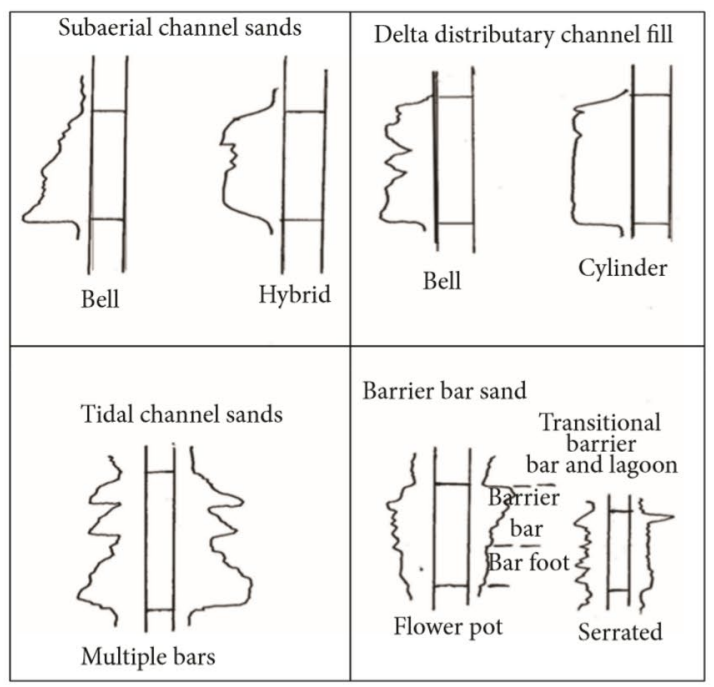

(a)

\section{b}

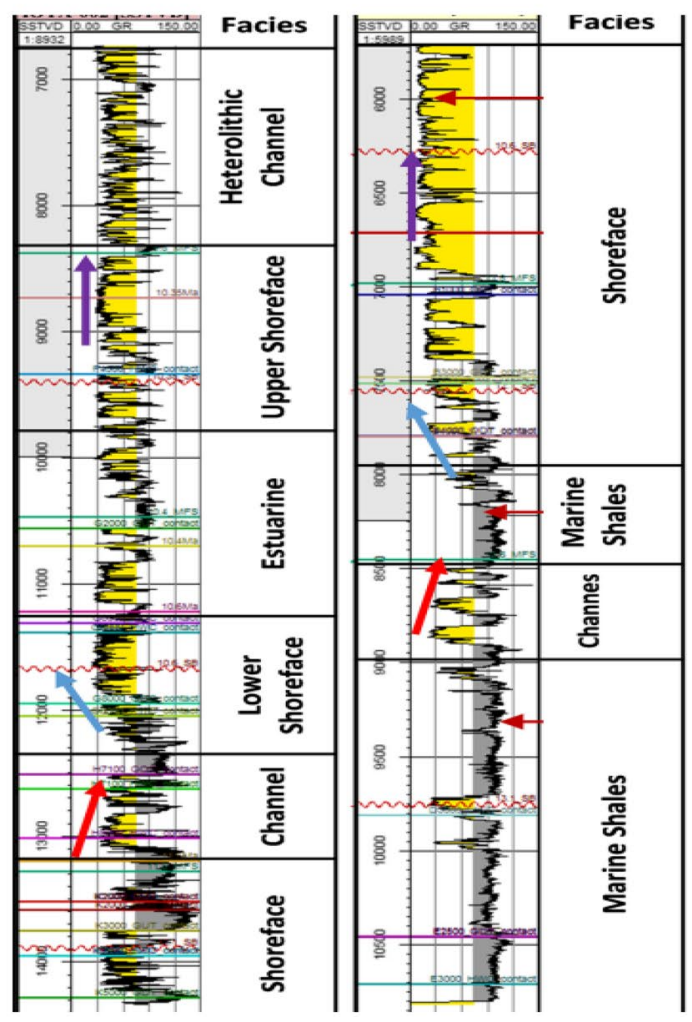

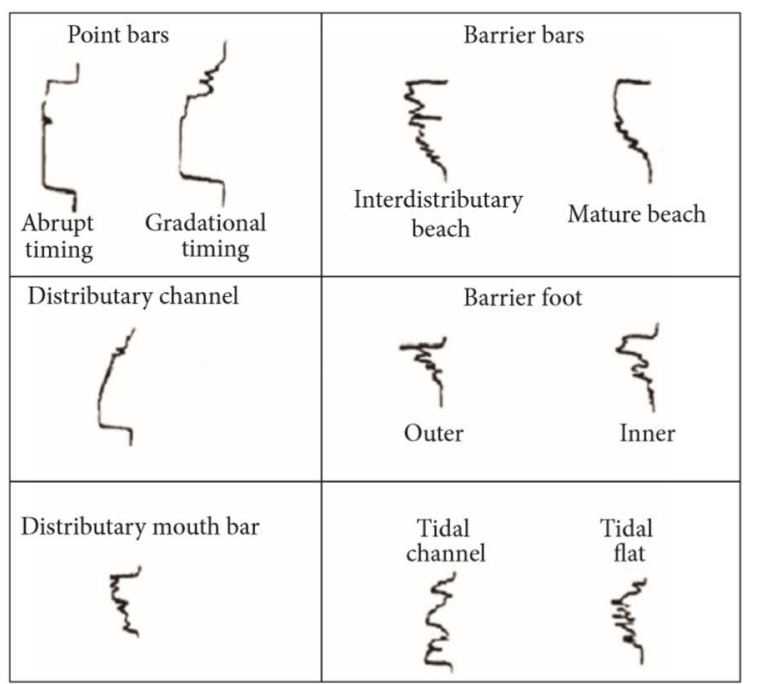

(b)

\section{LEGEND}

Lithologic Units

Sandstone and
Siltstone Units

Mudrock Unit

Log Signature/Pattern

Bell-Shaped Pattern

Funnel-Shaped Pattern

Cylindrical-Shaped Pattern

Fig. 4 a Gamma ray and resistivity log shapes suggestive of depositional environment (Adapted from Aloa, et.al. 2013 b). Electrofacies in the wells across the study area. (Modified from Mode et. al. 2015)

to B7 is probably due to compaction resulting from overlying sedimentation. Average volumes of shale recorded are between 13.79 and $29.25 \%$, suggesting that these reservoirs are not clean. Reservoirs B2, B4 and B5 show evidence of hydrocarbon saturation with average resistivity values of
$28.80,23.19$ and $13.33 \Omega \mathrm{m}$, respectively. Each of the reservoirs has average $\mathrm{Sw}$ of $13.38,13.82$ and $20.32 \%$ which was considered poor and implies that hydrocarbon saturations is good. Based on the negative crossing of the neutron and density logs by implication the hydrocarbon in reservoir B2 
Table 1 Summary of Biozonation in well-1(Foraminifera) (SPDC 2010)

\begin{tabular}{|c|c|c|c|c|c|}
\hline Top Depth & Bottom Depth (ft) & F.Zone (SPDC) & $\begin{array}{l}\text { F-zone } \\
\text { Blow (1969) }\end{array}$ & $\begin{array}{l}\text { Reliability Gra- } \\
\text { dient }\end{array}$ & Remarks \\
\hline 0 & 4000 & & & & No Data \\
\hline 4030 & 4200 & F9600/F9700 & $\mathrm{N} 13 / \mathrm{N} 14$ & & Barren \\
\hline 4431 & 5106 & & & & Undiagnostic (practically barren) \\
\hline 5611 & 6900 & F9500/F9600 & N10/N12 & & Globorotalia foshi S.I \\
\hline \multirow[t]{4}{*}{6927} & 9855 & F9500 & N10 & 1 & $\begin{array}{l}\text { Globorotalia praefohsi/Globorotalia } \\
\text { peripheroacuta }\end{array}$ \\
\hline & Microfaunal Marker & & & & \\
\hline & 7662 & F9540 & N9 & 1 & Globorotalia peripheroa/Orbulina spp. \\
\hline & 9120 & F9520 & N8 & 1 & Orbulina spp./Praeorbulina sicana \\
\hline
\end{tabular}

Table 2 Summary Bio-zonation inwell-1 (Pollen) (SPDC 2010)

\begin{tabular}{lllll}
\hline P Zone & Top & Bottom & Reliability & Remarks \\
\hline & Depth & $\begin{array}{l}\text { Depth }(f t) \\
3340\end{array}$ & Gradient & \\
& 0 & 3559 & 4 & No data \\
P830 & 3342 & 3530 & & No data \\
& 3560 & 3930 & 1 & q.b. 292 \\
P820 & 3935 & 4030 & 1 & \\
P780 & 4104 & 4164 & 1 & t. 440 \\
P770 & 4431 & 4605 & 1 & t.r. \&b.r. 320 \\
P740 & 4720 & 7332 & 3 & b. 17 \\
P720 & 7465 & 8798 & 2 & \\
P680 & 9007 & 9790 & &
\end{tabular}

is gas, and the gas-water-contact (GWC) was delineated at about 5986 feet. Reservoirs B4 and B5 are probably hydrocarbon filled with little or no formation water. This probably explains the tracking together of density and neutron logs signatures. Reservoirs B1, B3, B6 and B7 are water saturated with little or no hydrocarbon based on the low
Table 4 Summary of Bio-zonation in well- 2 (Pollen) (SPDC 2010)

\begin{tabular}{lllll}
\hline P Zone & Top & Bottom & Reliability & Remarks \\
\hline & Depth & Depth $(f t)$ & Gradient & \\
& 0 & 4400 & & No data \\
P820 & 4490 & 4590 & & \\
& 4610 & 5960 & & No data-Sandy \\
P740 & 5990 & & & ( high occ. of 320) \\
P720 & 6050 & 6710 & & \\
\hline
\end{tabular}

resistivity values observed. The average moveable hydrocarbon index (MHI) values of reservoirs 0.356, 0.426, 0.480 and 0.505 for the respective reservoirs, indicative of good fluid moveability.

\section{Petrophysical analysis of Well-3 reservoirs}

Well-3 is located in between Well-1 and Well-2 in the central part of the Don Field (Fig. 1a). The reservoir units' average thickness ranges between 113 feet in reservoir C7 and

Table 3 Summary of Bio-zonation in well - 2(Foraminifera) (SPDC 2010)

\begin{tabular}{|c|c|c|c|c|c|}
\hline Top Depth & Bottom Depth $(f t)$ & F.Zone (SPDC) & $\begin{array}{l}F \text {-zone } \\
\text { Blow } 1969\end{array}$ & $\begin{array}{l}\text { Reliability } \\
\text { Gradient }\end{array}$ & Remarks \\
\hline 0 & 3700 & & & & No Data \\
\hline 3795 & 4250 & & & & Undiagnostic \\
\hline 4310 & 4790 & F9600/F9700 & N13/N14 & & \\
\hline 4850 & 6170 & & & & Practically Barren \\
\hline 6290 & 7970 & F9500 & N10 & 3 & Globorotalia praefohsi/Globorotalia peripheroacuta \\
\hline \multirow[t]{4}{*}{8030} & 10,640 & F9300 & N7 & 4 & Praeorbulina sicana/Catapsydrax dissimilis \\
\hline & Microfaunal Markers & & & & \\
\hline & 6350 & F9540 & N9 & 3 & Globorotalia peripheroa/Orbulina spp \\
\hline & 7390 & F9520 & N8 & 3 & Orbulina spp./Praeorbulina sicana \\
\hline
\end{tabular}


211 feet in reservoir C5, while the sand thickness of these reservoirs ranged from 37 to 205 feet (Table 7). Average porosity values of $19.90 \%$ to $27.05 \%$ suggest good to excellent porosity. The average Vsh in these reservoirs ranged from 13.60 to $28.54 \%$ indicating that the reservoirs may
Fig. 6 Biofacies interpretation of the study area. (Abbreviations: $\mathrm{B}=$ Barren; $\mathrm{CD}=$ Coastal Deltaic; $\mathrm{PF}=$ Proximal Fluvial Marine; SHIN = Shallow Marine-to-Inner Neritic; IN = Inner Neritic; IN-MN =Inner Neritic-Middle Neritic; $\mathrm{MN}=$ Middle Neritic; MN-ON = Middle Neritic-to-Outer Neritic. $($ SPDC, 2010)

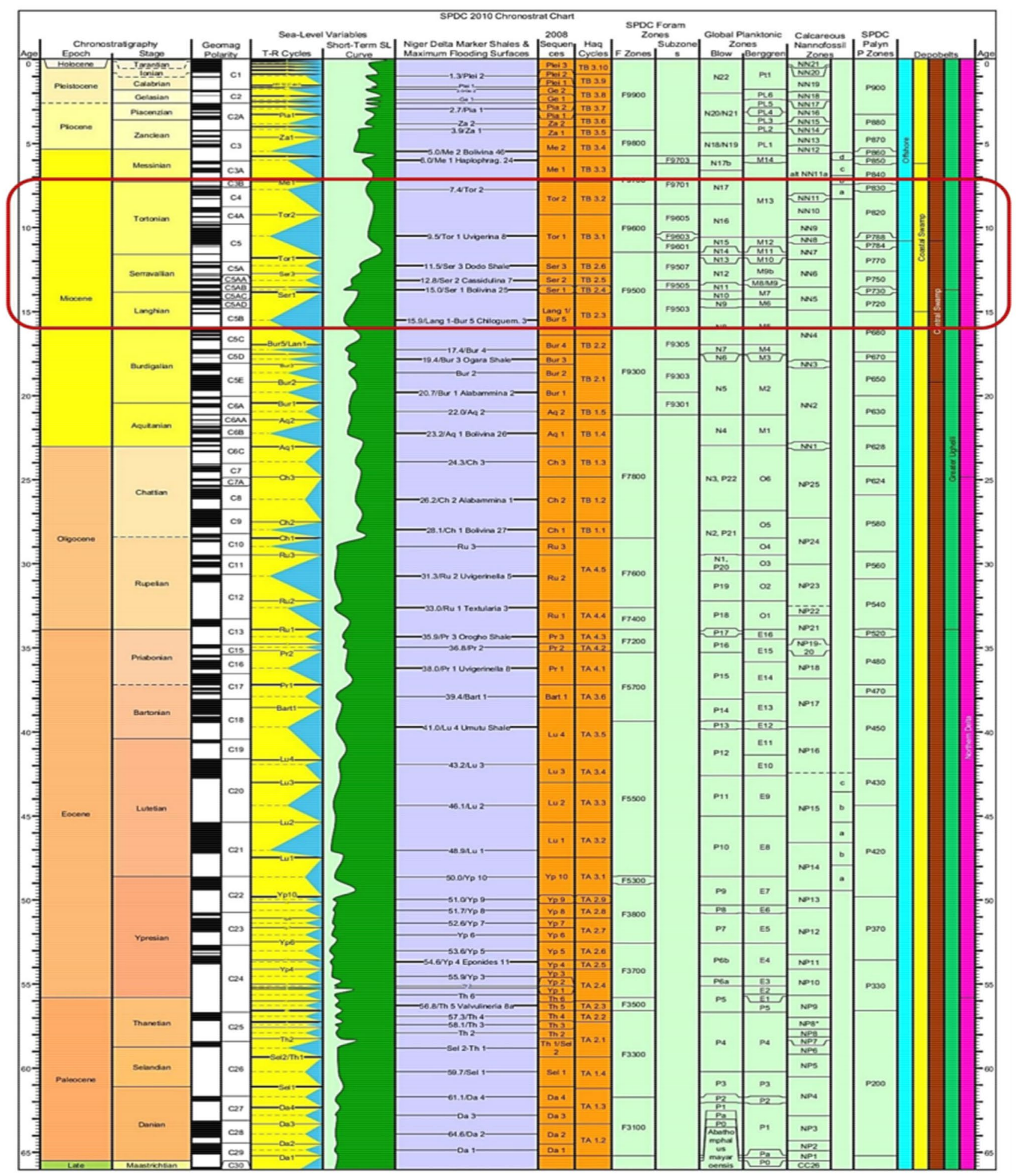

Fig. 5 Niger delta chronostrat chart of Shell Petroluem Development Company (SPDC, 2010) 


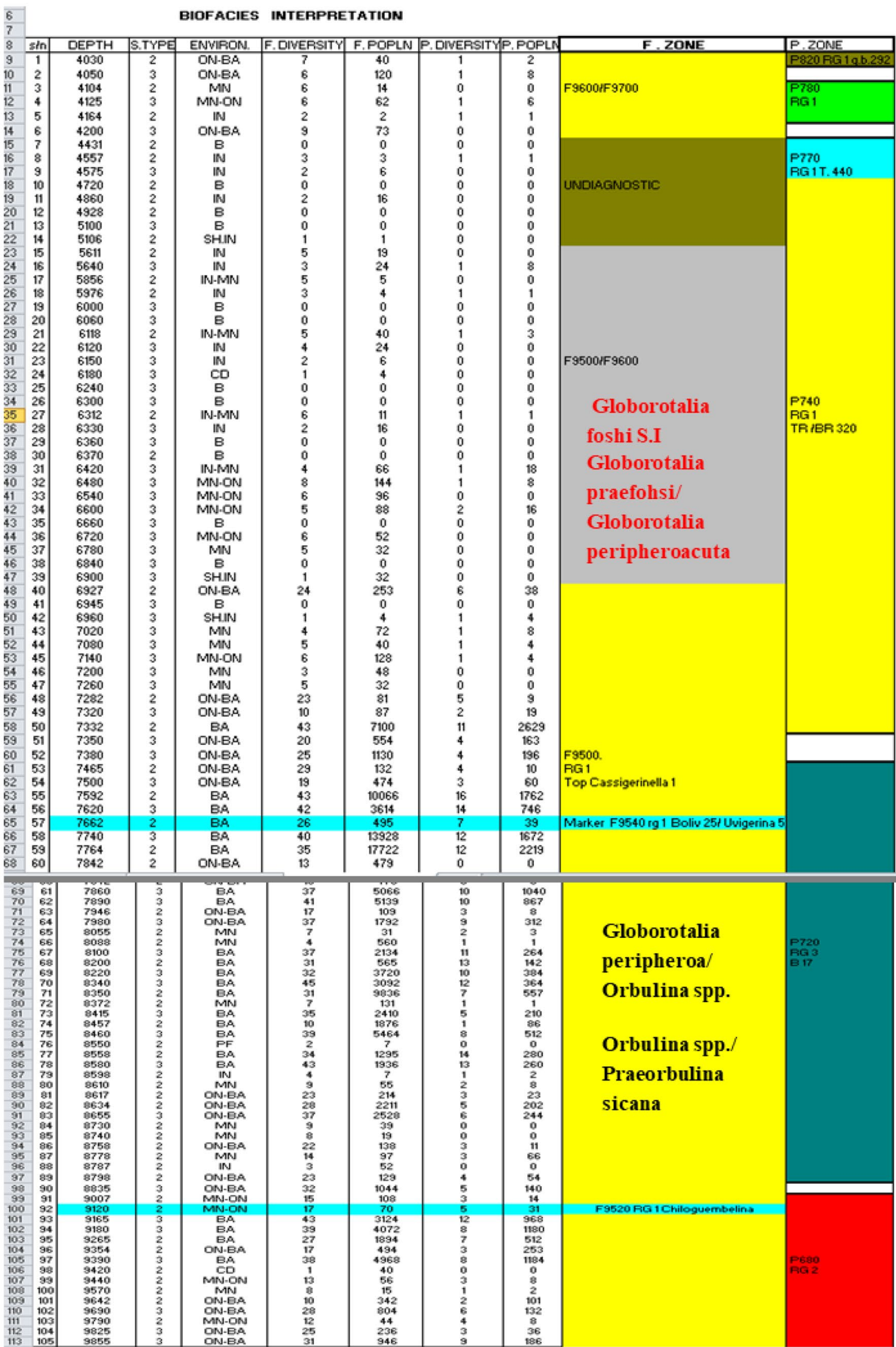


Table 5 Summary of Petrophysical results for Well-1

\begin{tabular}{llllllllll}
\hline $\begin{array}{l}\text { Reservoir } \\
\text { Unit }\end{array}$ & $\begin{array}{l}\text { Interval } \\
(\mathrm{ft})\end{array}$ & $\begin{array}{l}\text { Net } \\
\text { Sand } \\
(\mathrm{ft})\end{array}$ & $\begin{array}{l}\text { Average } \\
\text { Porosity } \\
(\%)\end{array}$ & $\begin{array}{l}\text { Average } \\
(\mathrm{md})\end{array}$ & $\begin{array}{l}\text { Average } \\
\text { Vsh } \\
(\%)\end{array}$ & $\begin{array}{l}\text { Average } \\
\text { MHI }\end{array}$ & $\begin{array}{l}\text { Average } \\
\text { Sw }(\%)\end{array}$ & $\begin{array}{l}\text { Average } \\
\text { Resistivity } \\
(\Omega \mathrm{m})\end{array}$ & $\begin{array}{l}\text { Fluid } \\
\text { Type }\end{array}$ \\
\hline A1 & $6960-7280$ & 313 & 21.51 & 152.98 & 5.37 & 0.37 & 79.41 & 1.5 & Water \\
A2 & $7350-7510$ & 110 & 21.12 & 273.24 & 18.63 & 0.26 & 30.12 & 1.96 & Water \\
A3 & $8360-8550$ & 117 & 21.11 & 1920.22 & 19.73 & 0.18 & 20.66 & 33.87 & Oil \\
A4 & $8800-8852$ & 39 & 18.92 & 22.76 & 13.29 & 0.34 & 40.6 & 1.14 & Water \\
A5 & $9535-9560$ & 15 & 16.07 & 131.08 & 28.96 & 0.43 & 43.50 & 26.54 & Oil \\
\hline
\end{tabular}

Table 6 Summary of Petrophysical Results for Well-2

\begin{tabular}{llllllllll}
\hline Reservoir unit & $\begin{array}{l}\text { Interval } \\
(\mathrm{ft})\end{array}$ & $\begin{array}{l}\text { Net sand } \\
(\mathrm{ft})\end{array}$ & $\begin{array}{l}\text { Average Porosity } \\
(\%)\end{array}$ & $\begin{array}{l}\text { Average } \\
\text { K } \\
(\mathrm{md})\end{array}$ & $\begin{array}{l}\text { Average } \\
\text { Vsh } \\
(\%)\end{array}$ & $\begin{array}{l}\text { Average } \\
\text { MHI }\end{array}$ & $\begin{array}{l}\text { Average } \\
\text { Sw }(\%)\end{array}$ & $\begin{array}{l}\text { Average } \\
\text { Resistivity } \\
(\Omega \mathrm{m})\end{array}$ \\
\hline B1 & $5883-5931$ & 30 & 23.39 & 1379.20 & 27.96 & 0.356 & $\begin{array}{l}\text { Fluid type } \\
27.60\end{array}$ \\
& $5961-5985$ & 35 & 22.97 & 772 & 13.79 & 0.571 & 13.38 & 28.80 & Was \\
B2 & $5986-6050$ & 52 & 26.98 & 1325.91 & 11.83 & 0.297 & 22.09 & 6.59 & Water \\
B3 & $6086-6370$ & 269 & 22.44 & 68.034 & 13.58 & 0.426 & 34.56 & 3.78 & Water \\
B4 & $6425-6469$ & 42 & 23.75 & 209.272 & 14.41 & 0.201 & 13.82 & 23.19 & Oil \\
B5 & $6490-6531$ & 41 & 24.36 & 161.03 & 15.96 & 0.273 & 20.32 & 13.33 & Oil \\
B6 & $6552-6624$ & 64 & 21.69 & 48.596 & 16.67 & 0.480 & 40.07 & 2.48 & Water \\
B7 & $6740-6800$ & 30 & 20.71 & 43.794 & 29.25 & 0.505 & 43.28 & 3.23 \\
\hline
\end{tabular}

Table 7 Summary of the Petrophysical Results for Well-3

\begin{tabular}{llllllllll}
\hline Reservoir unit & $\begin{array}{l}\text { Interval } \\
(\mathrm{ft})\end{array}$ & $\begin{array}{l}\text { Net sand count } \\
(\mathrm{ft})\end{array}$ & $\begin{array}{l}\text { Average } \\
\text { Porosity } \\
(\%)\end{array}$ & $\begin{array}{l}\text { Average } \\
\mathrm{K} \\
(\mathrm{md})\end{array}$ & $\begin{array}{l}\text { Average } \\
\text { Vsh } \\
(\%)\end{array}$ & $\begin{array}{l}\text { Average } \\
\text { MHI }\end{array}$ & $\begin{array}{l}\text { Average } \\
\text { Sw }(\%)\end{array}$ & $\begin{array}{l}\text { Average } \\
\text { Resistivity } \\
(\Omega \mathrm{m})\end{array}$ & $\begin{array}{l}\text { Fluid type } \\
\text { (\%) }\end{array}$ \\
\hline $\mathrm{C} 1$ & $8201-8256$ & 53 & 27.05 & 54.10 & 18.79 & 0.077 & 27.05 & 1.10 & Water \\
C2 & $8279-8395$ & 65 & 25.92 & 115.14 & 27.45 & 0.031 & 25.92 & 3.39 & Water \\
C3 & $8474-8576$ & 97 & 26.14 & 114.514 & 13.60 & 0.032 & 26.14 & 3.04 & Water \\
C4 & $8750-8834$ & 72 & 24.09 & 354.948 & 21.30 & 0.012 & 24.09 & 67.81 & Oil \\
C5 & $9045-9256$ & 205 & 23.88 & 555.327 & 15.12 & 0.009 & 23.88 & 201.58 & Oil \\
C6 & $9308-9371$ & 40 & 24.60 & 82.04 & 28.54 & 0.034 & 24.60 & 2.91 & Water \\
C7 & $9485-9598$ & 37 & 19.90 & 62.12 & 27.82 & 0.047 & 19.90 & 5.25 & Water \\
\hline
\end{tabular}

Table 8 Summary of sand master report Along Hole Depth for Well-2

\begin{tabular}{|c|c|c|c|c|c|c|c|c|c|c|c|}
\hline $\begin{array}{l}\text { Form } \\
\text { Code }\end{array}$ & $\begin{array}{l}\text { Top } \\
\text { Depth(ft) }\end{array}$ & $\begin{array}{l}\text { Base } \\
\text { Depth(ft) }\end{array}$ & $\begin{array}{l}\text { Net } \\
\text { Gas }\end{array}$ & $\begin{array}{l}\text { Net } \\
\text { Oil }\end{array}$ & $\begin{array}{l}\text { Highest } \\
\text { Oil }\end{array}$ & GDT & OUT & ODT & HCWC & WUT & $\begin{array}{l}\text { Ave } \\
\text { Por }\end{array}$ \\
\hline \multicolumn{12}{|l|}{ D } \\
\hline 30,000 & 5962 & 6056 & 17 & 10 & & & & & 5992 & & 30 \\
\hline \multicolumn{12}{|l|}{ D } \\
\hline 40,000 & 6086 & 6338 & & 13 & 6090 & 5979 & 5982 & & & 6106 & 29 \\
\hline \multicolumn{12}{|l|}{ D } \\
\hline 50,000 & 6408 & 6470 & & 52 & 6418 & & & 6106 & & & 27 \\
\hline \multicolumn{12}{|l|}{ D } \\
\hline 60,000 & 6488 & 6534 & & 33 & 6494 & & & & 6522 & & 27 \\
\hline \multicolumn{12}{|l|}{ E } \\
\hline 70,000 & 7810 & 7884 & & & & & & & 7844 & & 28 \\
\hline
\end{tabular}


Table 9 Summary of sand master report Along Hole Depth for Well-3

\begin{tabular}{|c|c|c|c|c|c|c|c|c|c|c|c|}
\hline $\begin{array}{l}\text { Form } \\
\text { Code }\end{array}$ & $\begin{array}{l}\text { Top } \\
\text { Depth(ft) }\end{array}$ & $\begin{array}{l}\text { Base } \\
\text { Depth(ft) }\end{array}$ & $\begin{array}{l}\text { Net } \\
\text { Gas }\end{array}$ & $\begin{array}{l}\text { Net } \\
\text { Oil }\end{array}$ & $\begin{array}{l}\text { Highest } \\
\text { Oil }\end{array}$ & GDT & OUT & ODT & HCWC & GUT & $\begin{array}{l}\text { Ave } \\
\text { Por }\end{array}$ \\
\hline \multicolumn{12}{|l|}{ E } \\
\hline 7000 & 8739 & 8839 & 85 & & & & & & & 8754 & 22 \\
\hline \multicolumn{12}{|l|}{ E } \\
\hline 7500 & 8930 & 8962 & & 18 & & & 8934 & 8952 & & & 21 \\
\hline \multicolumn{12}{|l|}{ E } \\
\hline 8000 & 9045 & 9258 & 212 & & & & & & 9728 & & 24 \\
\hline \multicolumn{12}{|l|}{$\mathrm{U}$} \\
\hline 3000 & 9713 & 9819 & & 12 & & & & & & & 21 \\
\hline
\end{tabular}
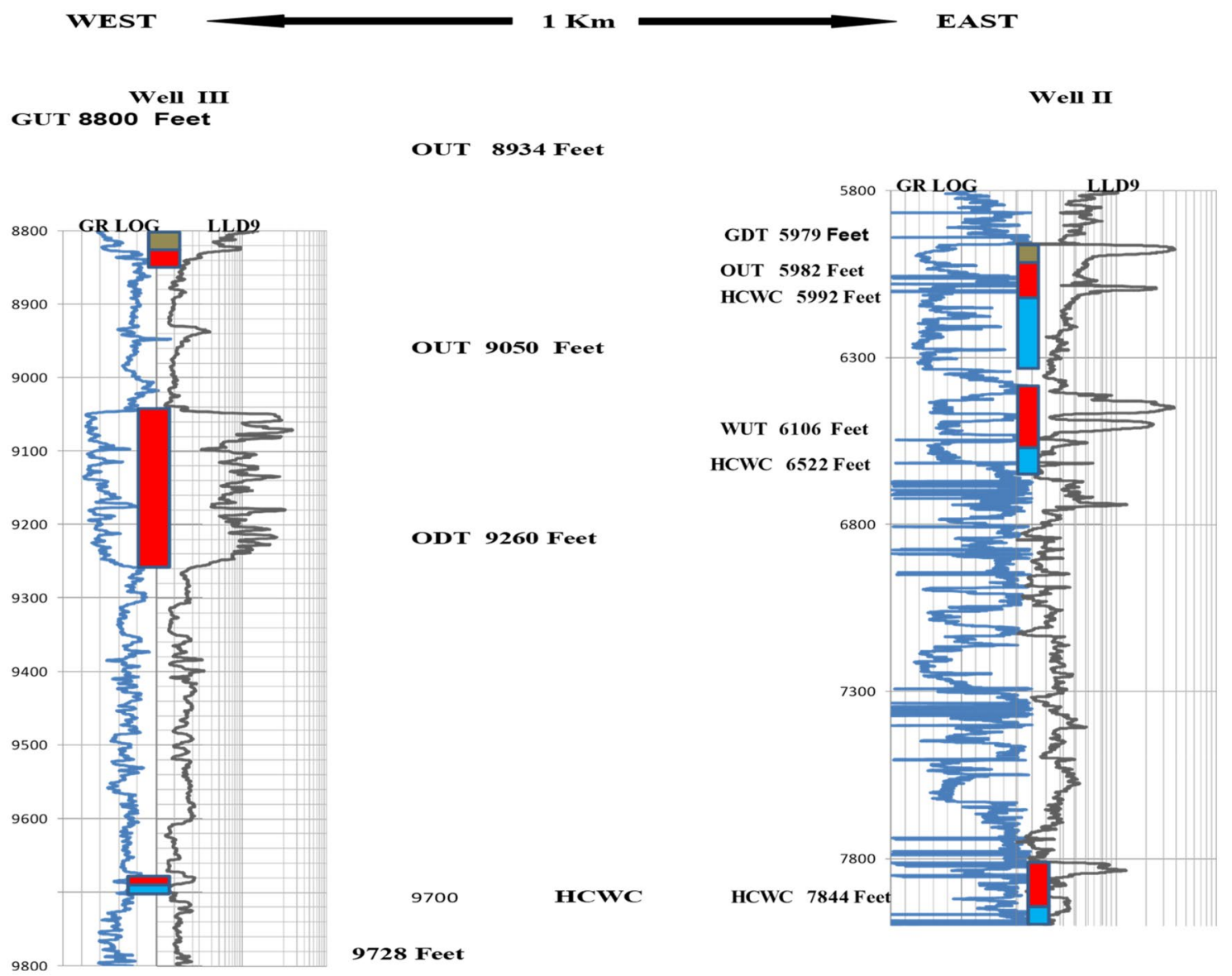

Fig. 7 Well logs showing the depths of GUT, GDT, OUT, ODT, WCWC and WUT

not contain clay types that could adversely affect quality in appreciable amounts. This is also reflected in the good to excellent average permeability values that ranged from $354.948 \mathrm{md}$ in reservoir $\mathrm{C} 4$ to $555.327 \mathrm{md}$ in reservoir C5. The reservoirs have good average porosity values that vary between $19.90 \%$ in reservoir C7 and $27.05 \%$ in reservoir $\mathrm{C} 1$. Reservoirs $\mathrm{C} 4$ and $\mathrm{C} 5$ have high resistivity values of 67.81 and $201.58 \Omega \mathrm{m}$, respectively. Water saturation within these reservoirs (i.e. between $24.09 \%$ and $23.88 \%$ ) suggests hydrocarbon saturation of $85.1 \%$ and $86.12 \%$, respectively. Reservoirs C1, C2, C3, C6 and C7 are water-bearing reservoir based on their low average resistivity values of 1.10 , $3.39,3.04,2.91$ and $5.25 \Omega \mathrm{m}$, respectively. Also their high average $\mathrm{Sw}$ value range of 19.90 and $27.05 \%$, suggests high water saturation with little or no hydrocarbon. The average moveable hydrocarbon index (MHI) values range from 0.009 to 0.012 indicating good fluid moveability. This is also 


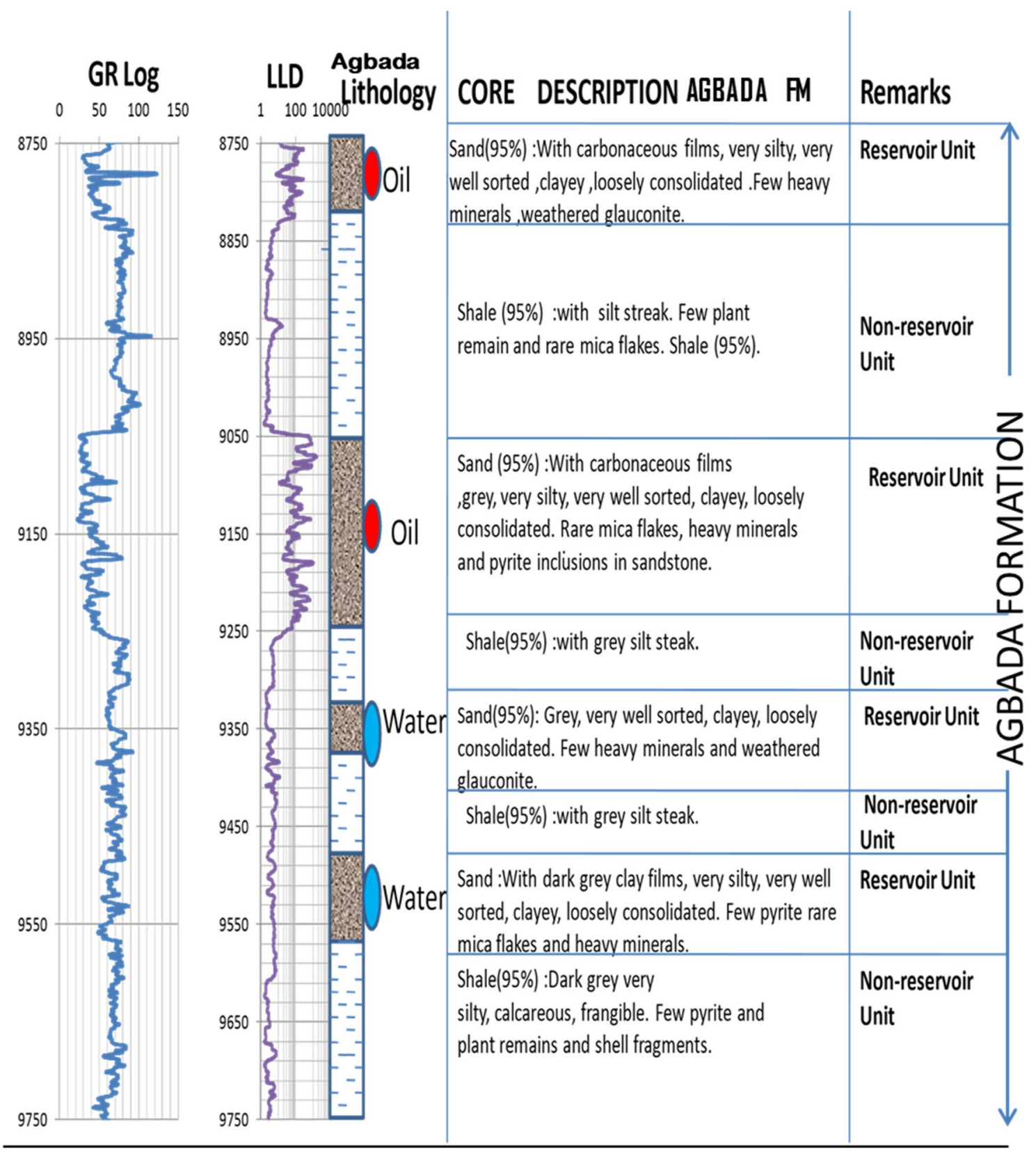

Fig. 8 Correlation between Well logs and Core data of well-3

confirmed by the reservoir permeability, where values as high as 354.948 and 555.327 md were observed.

\section{Depth of hydrocarbon occurrence}

The depths where hydrocarbons occur in a reservoir, especially at the contact zones are marked by increase in resistivity values. Result analysis shows that the depth of hydrocarbon occurrence varies from well to well due to variations in thickness of the overlying sediments, and possibly faulting (Anyiam et. al. 2019). The sand master report of well-2 and well-3 used in the determination of hydrocarbon depth of occurrence shows the fluid contacts within the reservoir, such as, hydrocarbon water contact (HCWC), gas down to (GDT), gas up to (GUT), oil up to (OUT), oil down to (ODT), water up to (WUT) and oil water contact (OWC) 
ST

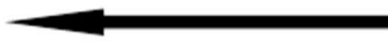

$1.4 \mathrm{Km}$

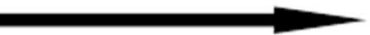

$\mathrm{NE}$

Well -1

Well -2

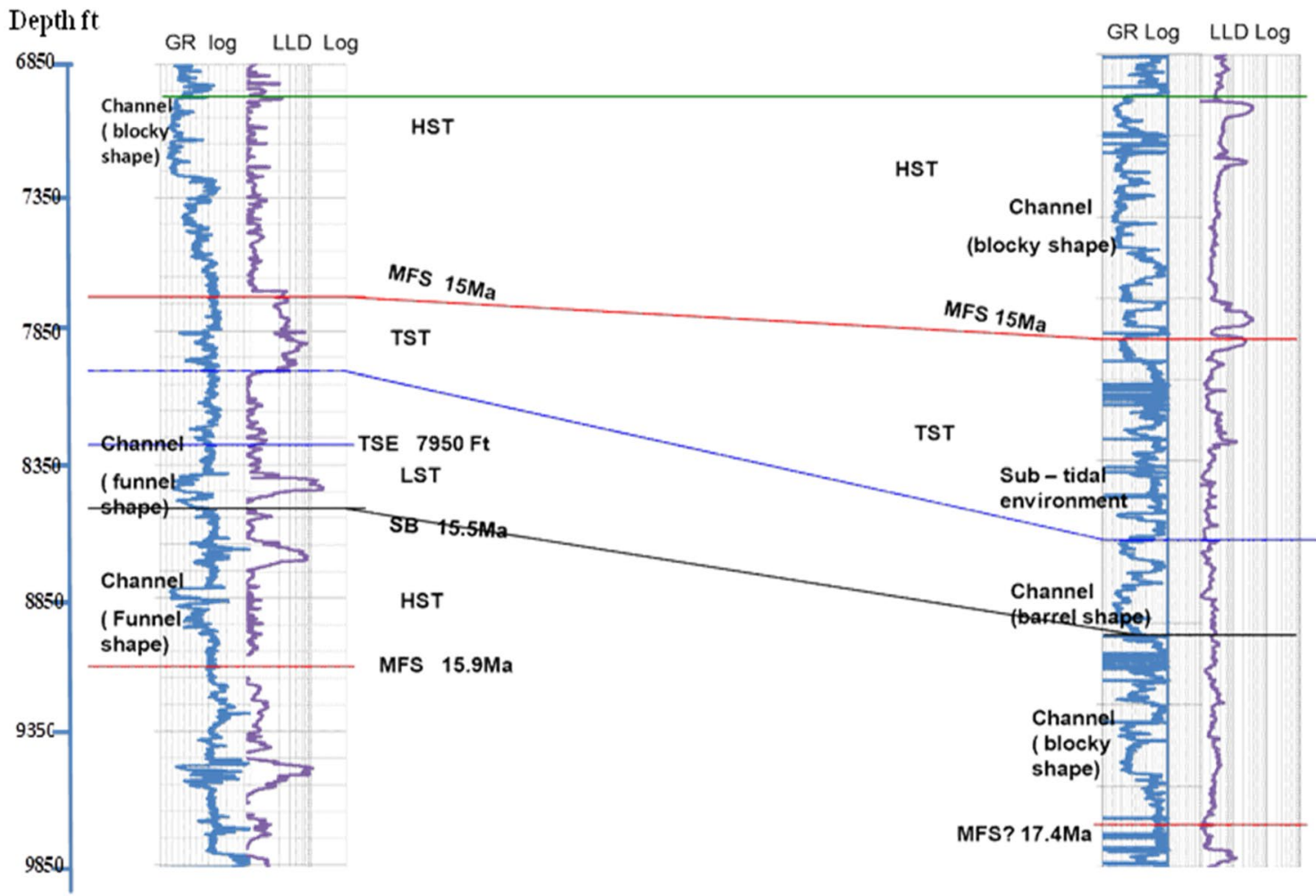

Fig. 9 Electrosequence stratigraphic Interpretation of the Well logs showing the positions of MFS, SB (erosional) with different Systems Tracts

(Tables 8 and 9). In well-2, the depth of 5982 feet marks OUT indicating the depth of hydrocarbon occurrence, while in well-3, the GUT and OUT at depths of 8754 and 8934 feet, respectively, show the zones of hydrocarbon accumulation (Fig. 7).

\section{Core data analysis}

Representative core data from well-3 were gotten from the interval between 8770 and 9890 feet. Core description shows physical and chemical characteristics of the lithologic intervals Revil et al. 2002; Glover 2010). The analysis was based on the sidewall sample description (Fig. 8). The genetic facies identified were the lower shoreface, upper shoreface, marine shale, tidal channel and channel heterolithics according to Mode et al. (2015) (Fig. 4b). The depositional environments spans through incised canyons, channels, inner mid shelf, shelf margin, and slope margin. The reservoir units represent intervals that are rich in sandstones (89 to $98 \%$ of sand). Such intervals contain grey, silty, well sorted and loosely consolidated sands with presence of few heavy minerals, pyrite, rare mica flakes and weathered glauconite (Fig. 8). The sorting and poorly consolidated natures of pore throats of sand grains in the reservoir units imply that these reservoir units have good fluid moveability. The result shows that reservoir intervals evaluated have good porosity and permeability qualities due to sphericity and good sorting of the grains. However, the presence of heavy minerals and clayey particles could reduce porosity and permeability qualities of rocks, because these particles could form pore throat blockages between sand grains thereby reducing pore radius and thus porosity and permeability. The core result shows the occurrence of different lithofacies at depths of 8824, 8830, 9256 and 9259 feet. At certain depths, there are non-reservoir intervals due to protrusion towards the south most position as observed in Well-1 (Fig).

\section{Lithologic identification}

Petrophysical and core analysis for depths between 8750 and 9750 feet shows that low gamma-ray log and high gammaray $\log$ values were recorded for the sand and shale units, 


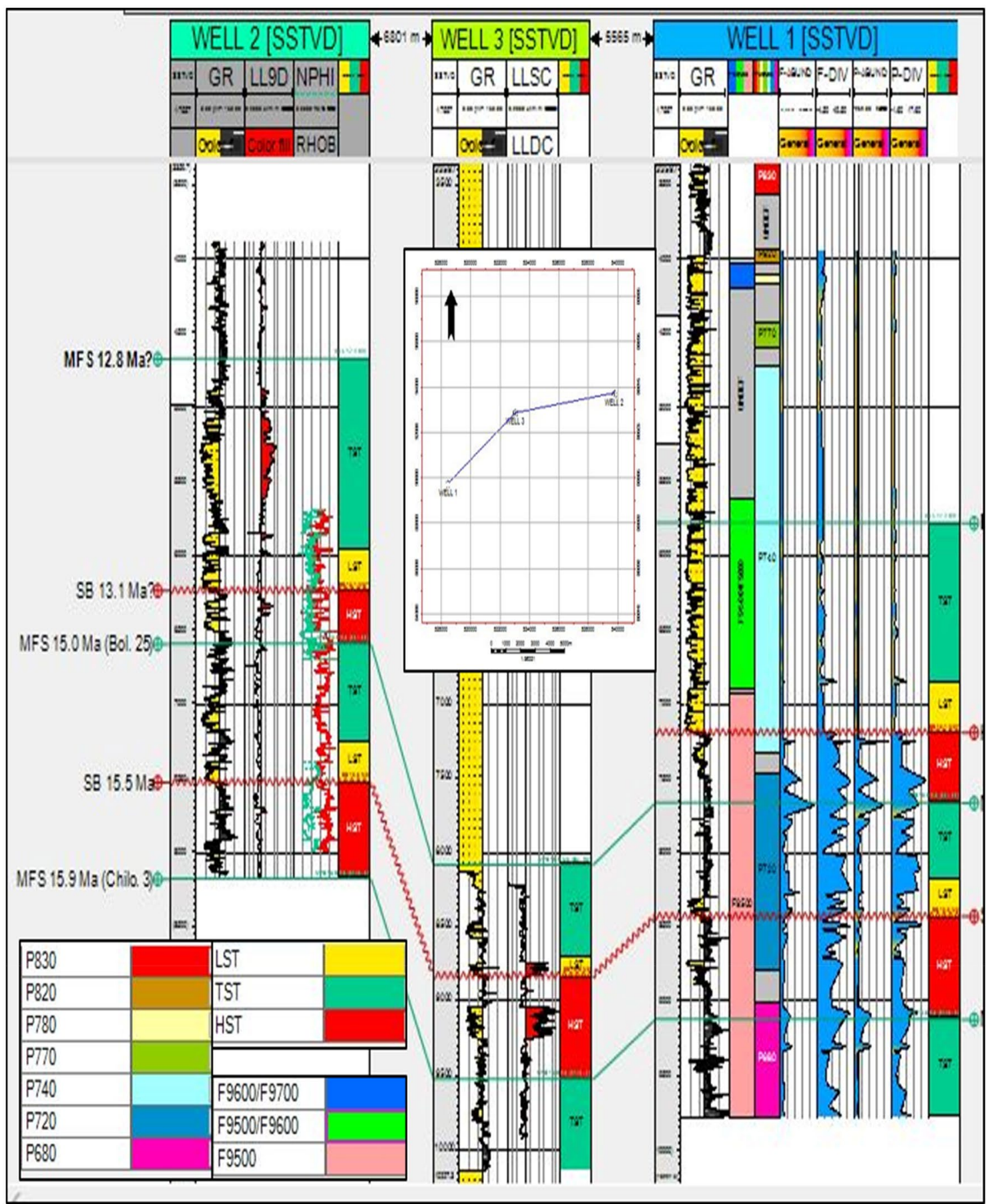

Fig. 10 Electrosequence stratigraphic correlation panel across "Don-wells" showing the system tract and SPDC-Zonation Scheme: PZone $=$ Palynological Zone; F-Zone $=$ Foraminifera Zone

respectively. Gamma-ray log values recorded between 8750 and 8840 feet, 9050 to 9256 feet, 9308 to 9371 feet and 9485 to 9595 feet indicate the presence of reservoir units (Fig. 8). These depth ranges also agrees with the core description for those depths, where very high sand percentages in comparison to shale percentage were observed. The lithologic compositions within these intervals are mainly silts and well-sorted, loosely consolidated sands. On the other hand, between 8790 and 9050 feet, 9250 and 9357 feet and 9601 and 9763 feet, non-reservoir units were identified based on 
Fig. 11 Electrosequence analysis across "Don-wells" showing the stacking patterns
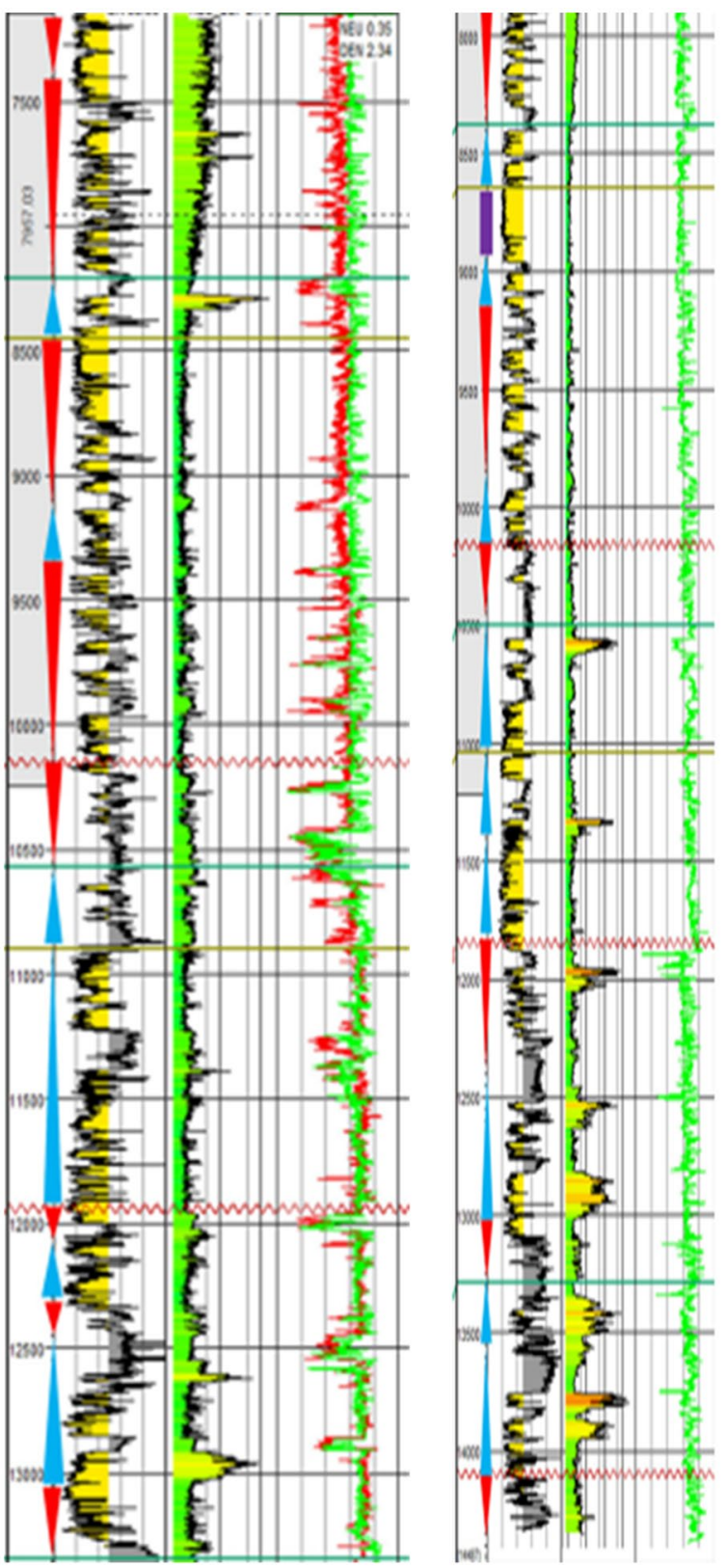
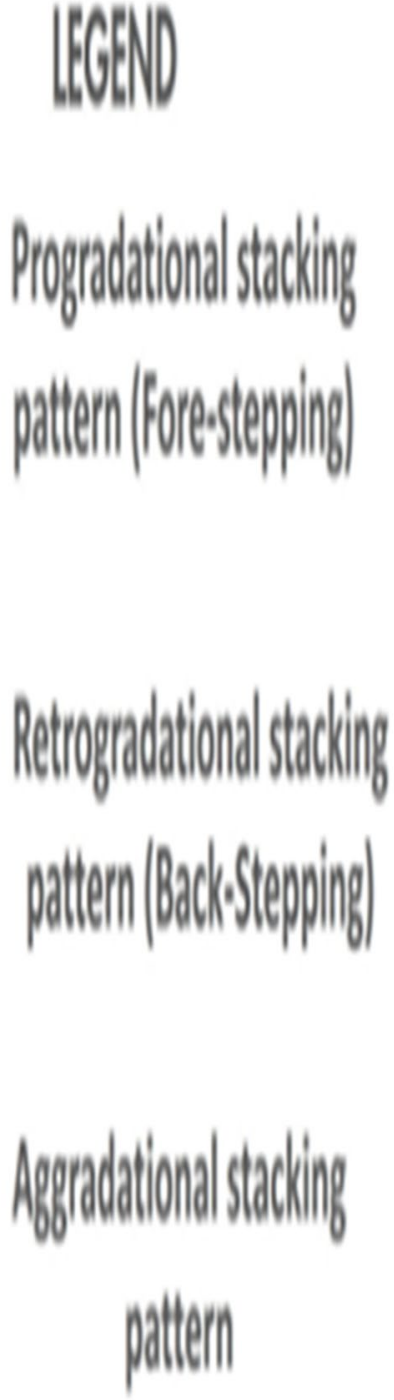

the relatively high gamma ray $\log$ values that indicate high percentage (i.e. > 90\%) composition of shale (Fig. 8).

\section{Fluid type identification}

The resistivity log and core description for depths between 8759 and 8840 feet and 9050 to 9256 feet show hydrocarbon reservoir units that have relatively high average resistivity values than adjacent water saturated reservoir units (Tables 5, 7 and 8). The sands were stained with carbonaceous films, especially at depths of 8824 and 9256 feet indicating the presence of hydrocarbon. Conversely, low resistivity values together with the absence of carbonaceous films were noted in other reservoir units, thus, this depicts water saturated zones, especially at depths of 8828 , 8833 and 9554 feet (Figs. 7 and 8). Water bearing intervals are outlined by low resistivity since resistivity increases when the formation water is replaced by oil while porosity remains constant. Also, density decreases when the water is replaced by oil in the formation with the same porosity, thus the hydrocarbon bearing intervals were not characterised at those points. (Archie, 1942). 


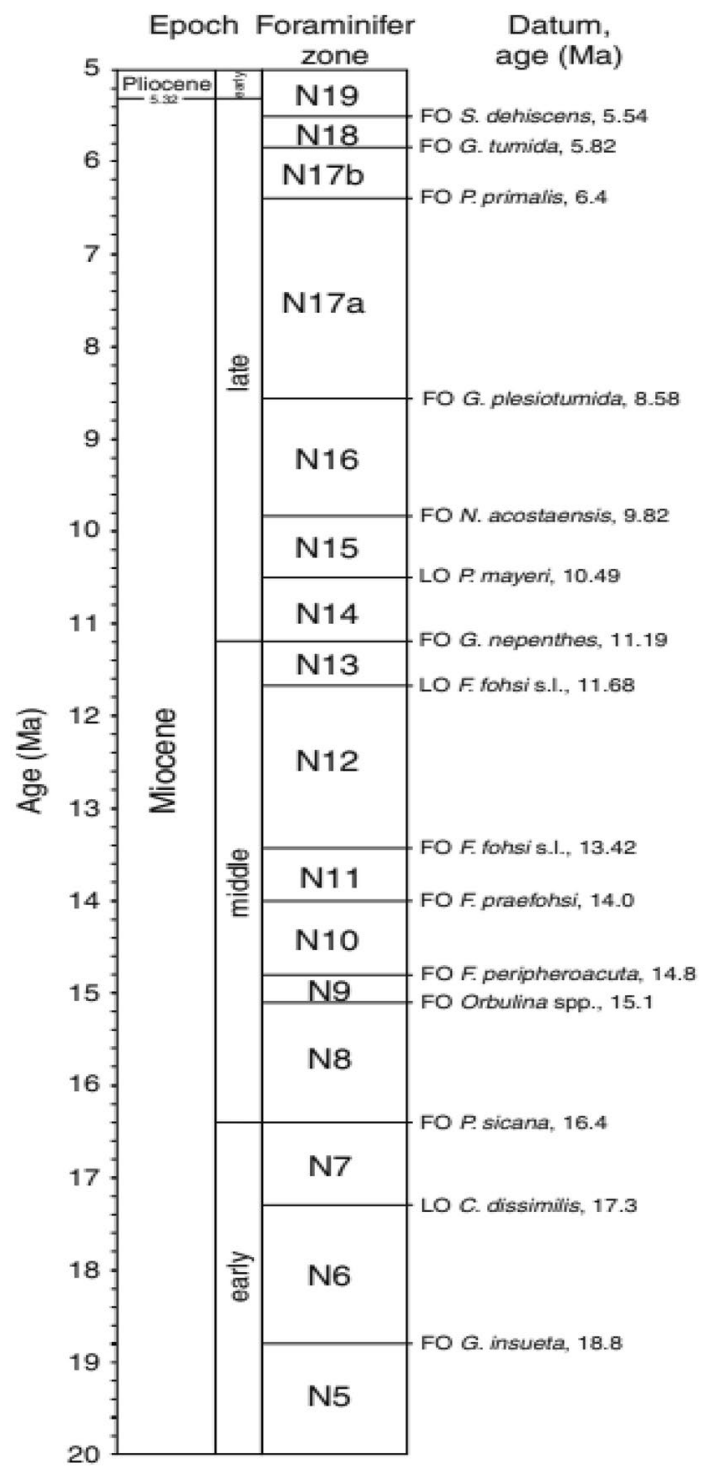

Fig. 12 Zonal scheme/bio-zone marker species, and ages, (Modified from Blow 1969)

\section{Presence of heavy minerals}

High gamma-ray responses observed at some clean sandstone intervals were as a result of the presence of heavy minerals such as weathered glauconite, pyrite and mica flakes. For better clarity, the integration of core data with well logs enhanced the determination and differentiation of these radioactive reservoirs from shale. The presence of weathered glauconite, mica flakes and pyrite generally indicates a transitional environment, i.e. coastal/marginal marine environment (Porrenga 1967; Prince 2018). In the studied intervals, glauconite is rare to common, while pyrite, shell fragments, ferruginous materials and mica flakes are very rare. Glauconite and pyrite are important accessory minerals used for environmental studies. Glauconite forms as an authigenic mineral during the early stage of diagenesis of marine sediment, and may also indicate slow rate of deposition (Smulikowski 1954; Hower 1961; McRae 1972; Odin and Matter 1981; Lewis and McConchie 1994; Amorosi 1995) and/or gap in deposition in a case of mature glauconitic mineral with mean potassium $\left(\mathrm{K}_{2} \mathrm{O}\right)$ content of $\sim 7 \%$ (Odin and Fullagar 1988). It is extremely susceptible to subaerial weathering and it is not known as a reworked second cycle detrital mineral (Selley 1997). The presence of glauconite in sand is an indication that the sand is of marine origin. This has also been reported by other researchers within the area from integrated evidences from sedimentology, stratigraphy, mineralogy and geochemical investigation (Lewis 1962; Adegoke et al. 1971 and 1976; Petters 1979 and 1982; Seiglie et al. 1982; Ojo 1996; Ozumba 1997; Fadiya 1998; Okosun and Liebau 1999; Chafetz and Reid 2000; Goki et al.2007 and Opeloye 2012). More so, pyrites within the shale units suggest reducing conditions. The combination of these accessory minerals with gamma-ray responses helped in sub-dividing the environment into regressive barrier bar, tidal sand wave, and tidal channels Mode et al. (2015). According to Prince (2018), these sub-environments suggest shoreface deposits in marginal marine settings (Fig. 4, 8 and 9).

\section{Electrosequence analysis}

Electrosequence involved the interpretation of gamma ray and resistivity log for diagnostic characteristics such as trends, shapes, and abrupt breaks, which are indicative of the depositional environment and energy of deposition (Serra and Sulpice, 1975). The analysis revealed facies ranging from Marine-Shale, Heterolithic channels, upper and lower shorefaces, Shaly-Sandstone and/to Sandstone Facies (Fig. 4b). The depositional systems of Shoreface, prodelta, distributary, tidal and fluvial systems were deduced from gamma ray log signatures. The Bell-shaped log patterns on gamma ray logs indicate a fining upward trends or an upward increase in gamma ray value (typical feature of fluvial channel deposits). The Funnel-shaped log patterns indicate a coarsening upward trend, clearly showed deltaic progradation. Cylindrical (blocky or boxcar) log motif are on thick uniformly graded coarse grained sandstone unit, probably deposits of braided channel, tidal channel deposits (Fig. 4b, 9 and 11).

\section{Sequence stratigraphic interpretation}

The sequence stratigraphy analysis provided an opportunity to understand lithofacies, stacking patterns, depositional 


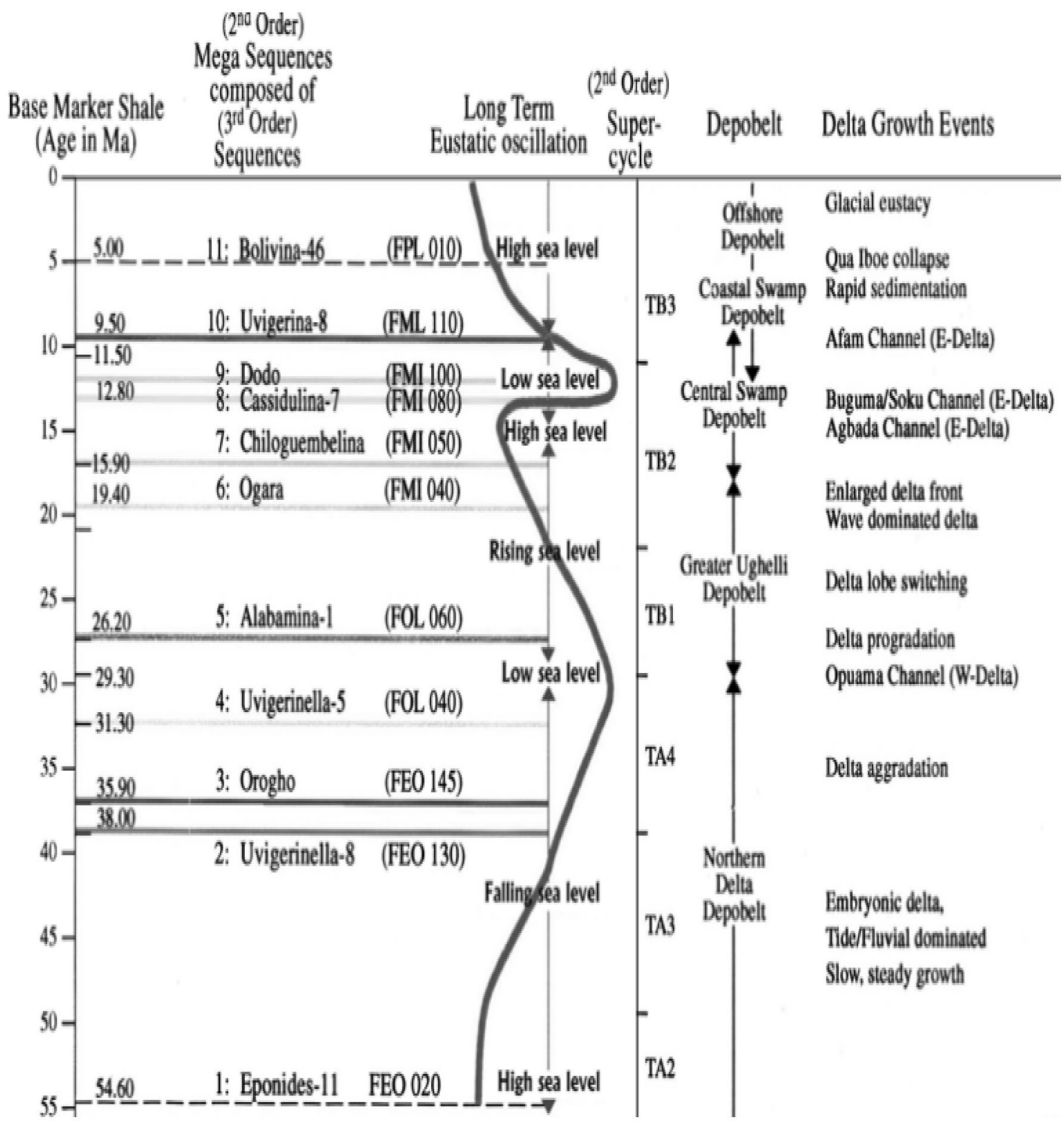

Fig. 13 Phases of delta evolution and some of their characteristics. (Adapted from Reijer 2011)

sequences and systems tracts distribution across the study area. The erosional sequence boundaries (SB) as observed are characterised by sizeable sand unit defined in well log by abrupt and sharp bases of thick low gamma ray value intervals usually separating coarsening-upwards intervals from fining upwards intervals (Fig. 10 and 11). The maximum flooding surfaces (MFSs) are characterised by thick and extensive shale units defined by thick high gamma ray value intervals that separate overall fining-upward interval from coarsening-upwards intervals, and high abundances and diversity of microfossils (Fig. 10 and 11). These stratal surfaces were delineated using floral and faunal abundance and diversity combined with palynological and foramimiferal zones encountered. Consequently, the stratigraphy of Niger Delta sections has conventionally been based on biochronological interpretations of fossil spores and foraminifers. Palynological and foraminiferal biozones have proved to be reliable tools for large-scale correlations between Hydrocarbon wells (Reijers, 2011). Following the planktonic foraminiferal zonal scheme of Blow (1969) as amended by Kenneth and Srinivasan (1983) (Fig. 12). The biostratigraphic framework and alphanumeric codes based on biostratigraphic zonation customised by the Shell Petroleum Development Company of Nigeria (SPDC) (Fig. 5 and 6) 
Table 10 Nature of 3rd-order composite sequences and their parasequence sets in the Niger Delta (Reijer 2011)

\begin{tabular}{|c|c|c|c|c|}
\hline $\begin{array}{l}\text { Sequence } \\
\text { MAIN SHALE } \\
\text { Secondary shale }\end{array}$ & Time span (ma) & Cycle (ma) & $\begin{array}{l}\text { Higher order } \\
\text { duration (ma) }\end{array}$ & Depobelt \\
\hline $\begin{array}{l}\text { Sequence } \\
\text { BOLIVINA-46 }\end{array}$ & $5.00-0.00$ & $5.00(\sim)$ & $0.83(-)$ & Offshore \\
\hline $\begin{array}{l}\text { Sequence } \\
\text { UVIGERINA-8 }\end{array}$ & $9.50-5.00$ & $4.50(\sim)$ & $1.50(\sim)$ & Offshore/central swamp \\
\hline $\begin{array}{l}\text { Sequence } 09 \\
\text { DODO SHALE }\end{array}$ & $11.50-9.50$ & $2.00(-)$ & $1.00(-)$ & Coastal/central swamp \\
\hline $\begin{array}{l}\text { Sequence } 08 \\
\text { CASSIDULINA }\end{array}$ & $12.80-11.50$ & $1.30(-)$ & $1.30(\sim)$ & Central/coastal swamp \\
\hline $\begin{array}{l}\text { Sequence } 07 \\
\text { CHILOGEMBELINA-3 }\end{array}$ & $15.90-12.80$ & $3.10(-)$ & $1.55(+)$ & Central/coastal swamp \\
\hline $\begin{array}{l}\text { Sequence } 06 \\
\text { OGARA SHALE }\end{array}$ & $19.40-15.90$ & $3.50(-)$ & $1.75(+)$ & Central swamp/ughelli \\
\hline $\begin{array}{l}\text { Sequence } 05 \\
\text { ALABAMINA-1 }\end{array}$ & $26.20-19.40$ & $6.80(+)$ & $1.36(\sim)$ & Ughelli \\
\hline $\begin{array}{l}\text { Sequence } 04 \\
\text { UVIGERINELLA- } 5\end{array}$ & $31.30-26.20$ & $5.10(\sim)$ & $2.55(+)$ & Ughelli/northern delta \\
\hline $\begin{array}{l}\text { Sequence } 03 \\
\text { OROGHO }\end{array}$ & $35.90-31.90$ & $4.60(\sim)$ & $1.53(+)$ & Northern delta \\
\hline Sequence 02 UVIGERINELLA- 8 & $38.00-35.90$ & $2.10(-)$ & $1.05(-)$ & Northern delta \\
\hline $\begin{array}{l}\text { Sequence } 01 \\
\text { EPONIDES-11 }\end{array}$ & $54.60-38.00$ & $16.60(+)$ & $1.51(+)$ & Northern delta \\
\hline
\end{tabular}

established planktonic foraminifera representation of middle Miocene zones N8 - N16 (Blow, 1969) and F9500-F9600/ F9700 (Shell zonation) in the study area (Tables 1-4). The Shell biozonation was published by Evamy et al. (1978). This zonation allows correlation across all facies types from continental to marine. These biozones are based on index planktonic and benthonic foraminifers recognised from transgressive marine shales (Petters, 1982). The regionally consistent marine marker shales, as well as some of the more local shales (Fig. 13 and Table 10), have usually been named after one of the marker species and are coded systematically (Fig. 5, 6 and 14).

The generated paleobathymetric map shows generally that sediments were deposited within neritic through bathyal environments, aligning with the progradational pattern of deposition of the Niger Delta (Fig. 15) (Emery and Myers, 1996; Kendall, 2003). Three MFS were mapped and dated paleontologically; 9.5 Ma (3980 feet), 12.8 Ma (5850 feet) and $15.0 \mathrm{Ma}$ (7662 feet) recognised as maximum shale peaks in Well-1, while MFS 15.9 Ma (9120 feet) was recognised in Well-2. Also, three SB were mapped and dated; $12.1 \mathrm{Ma}$ (4800 feet), 13.1 Ma (6250 feet) and 15.5 Ma (8450 feet) in well-1 and 15.9 Ma (9120 feet) in Well-2 (Fig. 10, 11 and Tables 1-4). The aforementioned ages indicate Langhian-Serivillian stage of Middle-late Miocene on the global geochronological scheme of Harland et al. (1990) (Fig. 14). Relative thickness of the systems tracts shows changes in rate of sedimentation caused by variations in local conditions like tectonics, effects of gravity, eustatic sea level changes and availability of accommodation space (Haq et al. 1988). Three systems tracts, namely the highstand systems tract (HST), the lowstand systems tract (LST) and the transgressive systems tract (TST) are all represented in Well-1, but in Well-2, only the highstand system tract (HST) and transgressive system tract (TST) were delineated. Sequence stratigraphic correlation across Well-1 and Well-2 shows thickening of sediment package from northeast to southwest (Figs. 9 and 10). This reveals the evidence of structural influence on stratigraphy which have been attributed to synsedimentary and gravity tectonics within the Niger Delta basin. The evolution of the Niger Delta basin is controlled by pre- and syn- sedimentary tectonic activities described by Evamy et al. (1978), Ejedawe et al. (1984), Knox and Omatsola (1989), Stacher (1995). Mode et al. (2015) agree that the occurrence of the identified sequence stratigraphic surfaces at different depths along dip and strike directions in the 


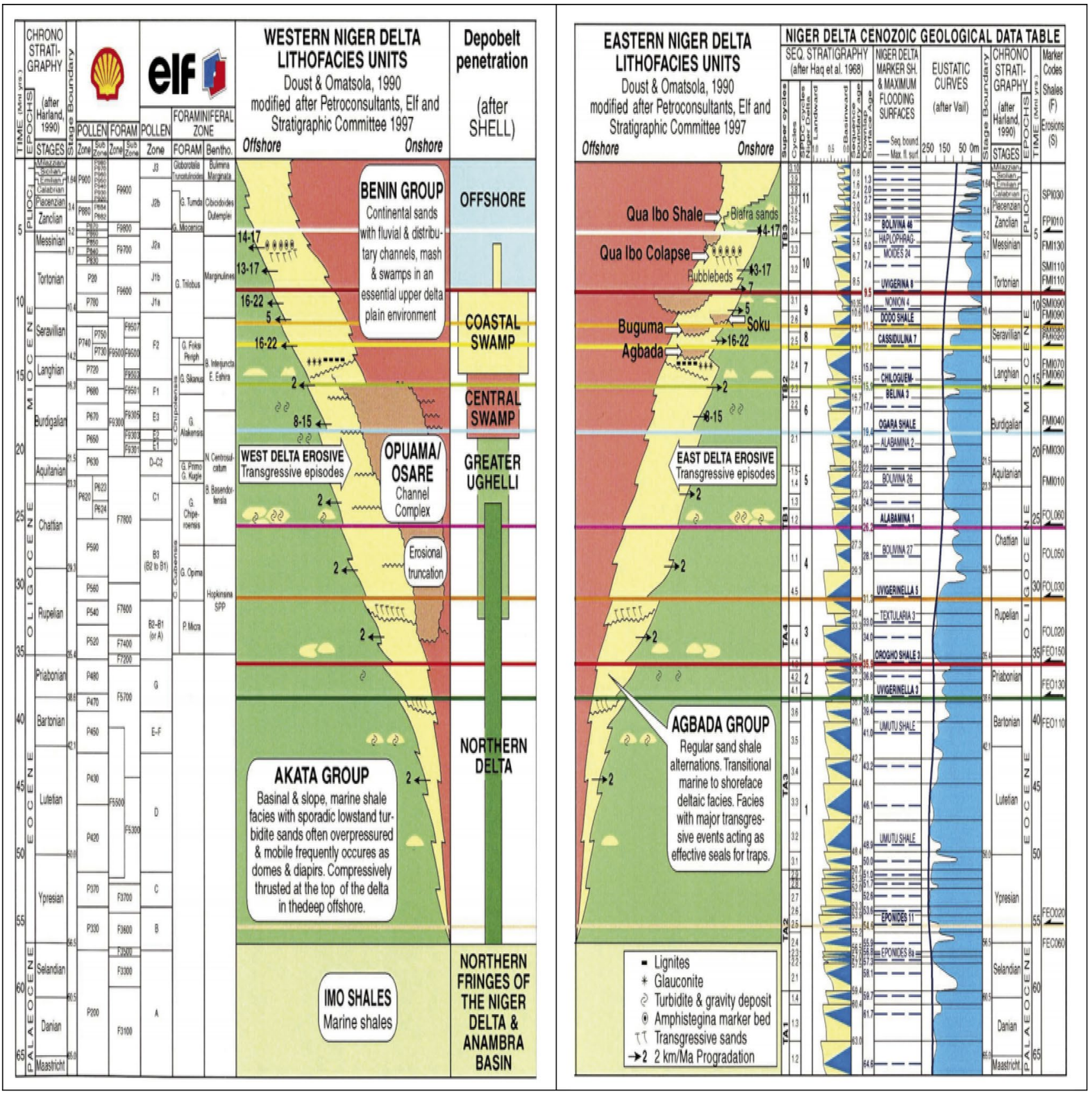

Fig. 14 Chronostratigraphic data sheet (west and east halves combined) of the Niger Delta. (Doust and Omatsola 1990)

wells shows evidence of faulting within the field. Hence, the sediments are thinner in the up-dip (northeast) section and thicken down-dip (southwest) with a corresponding decrease in net-to-gross values (Fig. 10). This thickening of sediment package down-dip could be attributed to the high rate of subsidence and deposition that is influenced by structures on stratigraphy (Evamy et al. 1978). Also, flattening at various MFS reveals a shift of depositional centres from the north to the south. The depositional sequences recognised were made up of genetic units of LST, TST and HST. The sands of LST and HST constitute the reservoir packages, whereas the shales of the TST in which most of the MFS were delineated serves as seal/cap rocks for the reservoir units. The alternation of reservoir units of the LST and HST, and the seal units of the TST offer good stratigraphic configurations for entrapment, hence, was the target for hydrocarbon exploration (Dim 2017). Sequence stratigraphic analysis was not carried out in Well-3 due to non-availability of sequence stratigraphic data for the well. The summary of the identified 


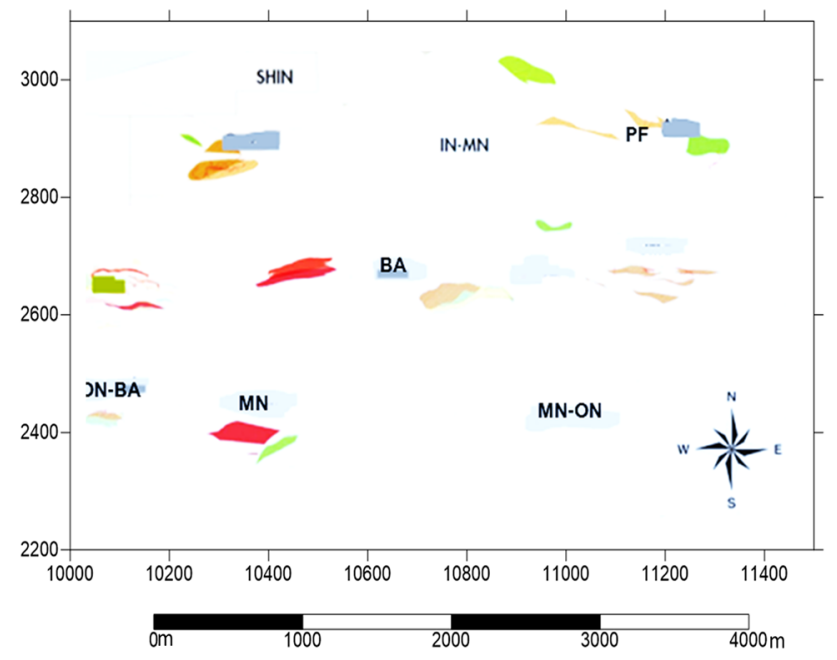

Fig. 15 The paleobathymetric map showing the depositional environments across the study area

systems tracts for the Wells in the study area is as shown (Table 11 and Figs. 9 and 10).

\section{Lowstand systems tract (LST)}

Sediments associated with lowstand systems tract in well-1 occur in incised valleys fill with coarse grained low-sinuosity channel or estuarine sandstone in response to sea level rise or shale prone wedge with thin fine grained turbidites forms on the slope lowstand prograding wedges. These sediments were deposited when relative sea level was at or near the shelf margin and rising slowly, but were slow enough for sedimentation to take place with shelf edge deltaic process (Posamentier and Vail 1988). The lowstand prograding wedge interval in well-1 is characterised by funnel deltaic sand body that laterally prograded into proximal lagoon shales. The prograding lowstand wedge complex is identified only in well-1 at a depth range of $8350-8560$ feet. This interval corresponds to channel fill environment with progradational parasequence set as shown. (Table 11 and Figs. 9, 10 and 11).

\section{Transgressive systems tract (TST)}

Transgressive systems tract develops as a result of increase in the rate of sea-level rise which has an overall deepening upward bathymetric signature. The rate of rise is at a maximum and sediment supply is more than the available space can accommodate. At this stage, the shelf is no longer in tune with the rising sea-level. Deltaic progradation ceases and sands are trapped up-dip in the estuaries (Scholle and Spearing 1998). Transgressive systems tract is observed in Well-1 (7750 to 78,340 feet and 9252 to 9760 feet) and Well-2 (6667-6700 feet) with maximum flooding surfaces (MFS $15 \mathrm{Ma}, 15 \mathrm{Ma}$ and $15.9 \mathrm{Ma}$ ) at the upper boundaries. The constant deepening interval above the lowstand tract in Well-1 at 8350 feet shows a proximal lagoon setting

Table 11 Summary of Identified systems tracts for well I

\begin{tabular}{|c|c|c|c|}
\hline Surfaces & & $\begin{array}{l}\text { Depth } \\
\text { (feet) }\end{array}$ & Remarks \\
\hline \multirow[t]{4}{*}{ SB (12.1 Ma) } & & 4800 & \\
\hline & LST & & $\begin{array}{l}\text { Consists of a progradational set of parasequences building out from the pre-existing continental slope character- } \\
\text { ised by shelf-edge deltas and shorelines }\end{array}$ \\
\hline & TST & & Consists of a retrogradational set of parasequences displays an overall deepening-upward succession \\
\hline & HST & & $\begin{array}{l}\text { Aggradational to progradational parasequence set with upward coarsening signature of blocky trends illustrating } \\
\text { a channel fill environment }\end{array}$ \\
\hline MFS(12.8 Ma) & & 5850 & \\
\hline SB (13.1 Ma) & & 6250 & \\
\hline \multirow[t]{4}{*}{ MFS (15 Ma) } & & 7662 & \\
\hline & TST & & $\begin{array}{l}\text { This system tract progressively deepens upward as successively younger parasequnces step further landward. It } \\
\text { shows constant high gamma ray values }\end{array}$ \\
\hline & TSE & 7950 & \\
\hline & LST & & $\begin{array}{l}\text { A prograding parasequence set with funnel(bow) stacking pattern, coarsening upwards showing a fill environ- } \\
\text { ment }\end{array}$ \\
\hline \multirow[t]{2}{*}{ SB (15.5 Ma) } & & 8450 & \\
\hline & HST & & $\begin{array}{l}\text { A prograding parasequence set that contains sets of condensed section with upward coarsening log spikes of a } \\
\text { typical shoreface environment }\end{array}$ \\
\hline \multirow[t]{2}{*}{ MFS(15.9 Ma) } & & 9120 & \\
\hline & TST & & $\begin{array}{l}\text { An overall deepening upward sequence show by the consistent high gamma ray values that indicate irregular } \\
\text { trends }\end{array}$ \\
\hline
\end{tabular}


that drowns the funnel lowstand wedge complexes (Kendall 2003). The proximal lagoon shales in Well-1 can serve as seal or cap rocks to the underlying channel fill reservoirs which contain hydrocarbon (Table 11 and Figs. 9, 10 and 11).

\section{Highstand systems tract (HST)}

This stage features a general decrease in sea level and it is characterised by initial aggradation of shales into intervals of shallowing-up facies. The rate of sea level rise is at a minimum and depositional rates exceed rate of sea level rise causing parasequences to build basinward in aggradational to progradational parasequence sets. Both fluvial and deltaic sands near the top of the unit prograde laterally into neritic shales. The highstand systems tract was identified in well- 1 and 2, respectively, at 6900-7500 feet and 8340-8860 feet for well-1, and between 5960 and 6600 feet for well-2. This prograding highstand complex corresponds to the shallow marine depositional environment. The coarsening upward sequence with frequent deepening well log spikes gives rise to a good to excellent porosity value with occasional shale intercalations that tend to reduce porosity and permeability. Furthermore, the shore sand of the highstand systems tract have good reservoir properties as stated by Coleman and Prior (1980) and Anyiam et al. (2019) (Table 11 and Figs. 9, 10 and 11).

\section{Conclusion}

The electrosequence, reservoir character and natural resources potentials of the 'Don Field' Central Swamp Depobelt of the Niger Delta were comprehensively assessed and delineated. All reservoirs units in the wells encountered were classified as good reservoirs based on their viable Petrophysical properties delineated through wirelogs and core analysis. The biostratigraphic analysis reveals sequence stratigraphic surfaces marked by MFS 9.5 Ma, 12.8 Ma, 15.0 Ma, 15.9 and SB 12.1 Ma, 13.1 Ma, 15.5 Ma and 15.9 Ma of middle-late Miocene with bio-zones range of N8-N16 or F9500-F9600/F9700 corresponding with fossil index abundance of Globorotalia foshi S.I; Globorotaliapraefohsi; Globorotaliaperipheroacuta; Orbulinaspp; Praeorbulinasicana; Paragloborotalia mayeri; Neogloboquadrina acostaensis. The electrofacies identified are lower shoreface, upper shoreface, marine shale, tidal channel, channel, and channel heterolithics. However, the presence of heavy minerals like pyrite and clay particles as noted in some of the reservoir may affect fluid moveabilty. The core and well $\log$ analysis divulges that sparse shale beds were also present, and the sandstone is composed of $89 \%$ quartz and about $11 \%$ clay and other minerals. The clay is a mixture of illite (60\%) and kaolinite (40\%). High resistivity values recorded at intervals where sand particles are discoloured by carbonaceous films indicate possibly hydrocarbon zones. The maximum flooding surface mark regional seals and caps the major reservoir units across the various fields in the study area. The LST and HST sand units of the basin floor fans, channel, and shoreface are potential good hydrocarbon reservoirs, whereas the marine shale units of the TST, which is capped by MFS, also provides regional seals to the reservoir units.

Acknowledgements We wish to thank Shell Petroluem Development Company (SPDC-Nigeria) for releasing the materials for this study. Also, we acknowleged the Department of Petroleum Resources (DPR) for their support in this research work by directing SPDC to release the relevant data for this project.

Funding This work is fully funded by the authors.

\section{Declaration}

Conflict of interests On behalf of all the co-authors (Mr Joseph Nnakuba, Mr Job Urang, Dr Ebong Dickson, Mr Joseph Eradiri and Dr Anthony Ugbaja), i the corresponding author, Mr Emmanuel Akaerue, states that there is no conflict of interest.

Open Access This article is licensed under a Creative Commons Attribution 4.0 International License, which permits use, sharing, adaptation, distribution and reproduction in any medium or format, as long as you give appropriate credit to the original author(s) and the source, provide a link to the Creative Commons licence, and indicate if changes were made. The images or other third party material in this article are included in the article's Creative Commons licence, unless indicated otherwise in a credit line to the material. If material is not included in the article's Creative Commons licence and your intended use is not permitted by statutory regulation or exceeds the permitted use, you will need to obtain permission directly from the copyright holder. To view a copy of this licence, visit http://creativecommons.org/licenses/by/4.0/.

\section{References}

Adegoke OS, Dessauvagie TFJ, Kogbe CA (1971) Planktonic Foraminifera in the Gulf of Guinea Sediments. Micropaleontology 17(2):197-213

Akaerue EI, Ita AO, Okonkwo AC (2018) Petrophysical evaluation of Etu Field Coastal Swamp I Depobelt Niger Delta, Nigeria. Elixir Earth Sci 119(2018):50989-50994

Alao PA, Ata AI, Nwoke CE (2013) Subsurface and Petrophysical Studies of Shalysand reservoir targets in Apete Field. Niger Delta, J Environ Earth Sci 2(3):56-72

Amorosi A (1995) Glaucony and Sequence Stratigraphy: A conceptual framework of distribution in siliciclastic sequences. J Sediment Res 65:419-425

Anyiam OA, Eradiri JN, Mode AW, Okeugo CG, Okwara IC, Ibemesi PO (2019) Sequence stratigraphic analysis and reservoir quality assessment of an onshore field, Central Swamp Depobelt, Niger Delta Basin. Nigeria Arabian J Geosci 12(24):791

Archie GE (1942) The Electrical Resistivity Log as an Aid in Determining Some Reservoir Characteristics. Trans AIME 146(1):5462. https://doi.org/10.2118/942054-G 
Blow WH, (1969). Late Middle Eocene to Recent Planktonic Foraminiferal Biostratigraphy. In: Proceedings 1st International Conference Planktonic Microfossils Bronnimann, P., and Renz, H.H. (Eds.), Geneva ,: Leiden (E.J. Brill), Vol.1: 199 - 422.Busch DA (1975). Influence of growth faulting on sedimentation and prospect evaluation. American Association of Petroleum Geologist. Bulletin, 59 (2): 217. ®230

Burke KC, Dessauvagie TFJ, Whiteman AJ (1972) Geological history of the Benue valley and adjacent areas. In: Dessauvagie TFJ, Whiteman AJ (eds) African geology. Ibadan University Press, Ibadan, pp 341-409

Chafetz HS, Reid A (2000) Syndepositional shallow-water precipitation of glauconitic minerals. Sedimentary Geology, 136(1-2), 29-42.Coleman JM, Prior DB (1980). Deltaic Sand Bodies, AAPG Continuing Education Course Note, Series No 15:p56-60

Corredor F, Shaw JH, Bilotti F (2005) Structural styles in the deep water fold and thrust belts of the Niger Delta. Am Assoc Petroleum Geol Bull (AAPG) 89(6):753-780

Daukoru JW. "PD 4(1) Petroleum Geology of the Niger Delta." Paper presented at the 9th World Petroleum Congress, Tokyo, Japan, May 1975.

Davies DK (2002). Foundation of Petrophysics. Petroskills Training, Vol B.Dim CIP (2017). Hydrocarbon Prospectivity in the Eastern Coastal Swamp Depo-belt of the Niger Delta Basin, Springer Briefs in Earth Sciences, https://doi.org/10.1007/ 978-3-319-44627-1

Doust H (1987). The Niger Delta. Hydrocarbon Potential of a major Tertiary Delta Province. KNGMG Symposium `Coastal Lowlands` Geology and Geotechnology. Kluwer Academic Publ. Netherlands, pp. 203 - 212.

Doust H, Omatsola E (1990) Niger Delta. In: Edwards JD, Santogrossi PA (eds) Divergent/passive Margin Basins, American Association of Petroleum Geologists Memoir 48. Tulsa, Oklahoma, USA, pp 201-238

Durand J (1995) High resolution sequence stratigraphy (genetic stratigraphy) in reservoir sedimentology: examples from the Niger Delta. Nigerian Assoc Petroleum Explorationists Bull 10:65-73

Ejedawe JE (1981) Patterns of incidence of oil reserves in Niger Delta Basin. Am Assoc Petroleum Geol Bull 65:1574-1585

Ejedawe JE, Coker SJL, Lambeth-Aikhionabare DO, Alofe KB, Adoh EO (1984) Evolution of oil-generative window and oil and gas occurrence in Tertiary Niger Delta Basin. American Association of Petroleum Geologists Bulletin 68, 1744-1751Ekweozor CM, Okoye NV (1980). Petroleum Source Bed Evaluation of Tertiary Niger Delta: Am Assoc Petroleum Geol Bull 64:1251-1259

Ekweozor CM, Daukoru EM (1994). Northern delta depobelt portion of the Akata-Agbada petroleum system, Niger Delta, Nigeria, in Magoon, L.B., and Dow, W.G., eds., The petroleum systemFrom source to trap: American Association of Petroleum Geologists Memoir 60, p. 599-613.

Emery D, Myers K (1996) Sequence stratigraphy. Blackwell, London, p 297

Etu-Efeotor JO (1997) Fundamentals of Petroleum Geology. Published byParagraphics (an imprint of Jeson services). Port Harcourt. Pp.62, 64, 146Evamy BD, Haremboure J, Kamerling P, Knaap WA, Molloy FA, Rowlands PH., (1978). Hydrocarbon habitat of the Tertiary Niger Delta. American Associa Tion of Petroleum Geologists Bulletin 62:1-39

Fadiya SL (1998).Foraminifera and Calcareous Nannofossil Biostratigraphy and Well Log Sequence Stratigraphic Analysis of Opobo-5 and Opobo-9 Wells, Niger Delta. Unpublished M.Sc thesis, Obafemi Awolowo University,Ile-Ife, Nigeria: 200p.

Frazier DE (1974) Depositional episodes: their relationship to the Quaternary stratigraphic framework in the northwestern portion of the Gulf basin: University of Texas at Austin, Bureau of Economic Geology Geological Circular 74-1, 28 p.
Galloway WE (1989a) Genetic stratigraphic sequences in basin analysis 1: Architecture and genesis of flooding surface bounded depositional units. Am Assoc Petroleum Geol Bull 73:125-142

Galloway WE (1989b) Genetic Stratigraphic Sequences in Basin Analysis 1: Architecture and Genesis of Flooding-Surface Bounded Depositional Units. Am Assoc Petroleum Geol Bull 73(2): $125-142$

Glover P. (2000). Petrophysics MSc Course Notes. Retrieved 23nd August, 2021, from http://www2.ggl.ulaval.ca/personnel/paglo ver/CD\%20Contents/GGL66565\%20Petrophysics\%20English/ Chapter\%2014.PDF

Goki NG, Mamman YD, Obaje NG, Opeloye SA, Chaanda MS (2007) PlanktonicAgglutinated Foraminiferal Associations in the Cretaceous Dukul Formation of the Nigerian Benue Trough. Global J Geol Sci 5:55-59

Haack RC, Sundararaman P, Diedjomahor JO, Xiao H, Gant NJ et al. (2000). Niger Delta petroleum systems, Nigeria. In M. R. Mello, \& B. J. Katz (Eds.), Petroleum systems of South Atlantic margins (pp. 213-231) (American Association of Petroleum Geologists Memoir 73).

Haq BU, Hardenbol J, Vail PR (1988). Mesozoic and Cenozoic chronostratigraphy and cycles of sea level changes. [In:] C.K. Wilgus, B.S. Hastings, H. Posamentier, J. van Wagoner, C.A. Ross \& C.G.S.C. Kendall (Eds): Sea-level changes - an integrated approach. SEPM Special Publication 42, 71-108.

Harland WB, Armstrong RL, Cox AV, Craig LE, Smith AG, Smith DG (1990) A geological time scale 1989. Cambridge University Press, Cambridge, p 263

Hilchie DW (1978) Applied Open-hole Log Interpretation: Golden, Colorado, D.W. Hilchie Incorporated, p. 309.Hospers J (1965). Gravity field and structure of the Niger Delta, Nigeria. West Africa Geol Soc A Bull 76:407-422

Hower J (1961) Some factors concerning the nature and origin of glauconite. Am Miner 46(3):313-334

Keelan, DK (1972). A critical review of core analysis techniques. J. Cdn. Petrol. Tech., 11 (2; Apr.- June): 42-55.

Kendall C (2003). Use of well logs for sequence stratigraphic interpretation of the subsurface. USC Sequence Stratigraphy Web. University of South Carolina. http://strata.geol.sc.edu/index

Kennett JP, Srinivasan MS (1983). Neogene planktonic foraminifera: A phylogenetic atlas. Stroudsburg, Pa: Hutchinson Ross.

Knox GJ., Omatsola ME (1989). Development of the Cenozoic Niger Delta in terms of the escalator regression model. [In:] Proceedings of the KNGMG Symposium 'Coastal Lowlands - Geology and Geotechnology'. Kluwer Academic Publishers, 181-202.

Ladipo KO (1992) Sequence stratigraphic analysis: an example of applications to prospect appraisal in the Northern (western) Niger Delta, Nigeria. Nigerian Assoc Petroleum Explorationists Bull 7:153-158

Larionov VV, (1969) Borehole Radiometry Moscow, U.S.S.R. In: Nedra, M.R.L. and Biggs, W.P., Eds., Using Log-Derived Values of Water Saturation and Porosity, Trans. SPWLA Ann. Logging Symp. Paper, 10, 26.

Lewis DW (1962). The paragenesis of glauconite in the Bliss Formation, Silver City, New Mexico. MS thesis, University of Houston, Houston, $158 \mathrm{pp}$

Lewis DW, McConchie D (1994). Practical Sedimentology, Chapman and Hall, New York (213 p.)

Magbagbeoloa O, Willis BJ (2007) Sequence stratigraphy and syndepositional deformation of the Agbada Formation, Robertkiri field, Niger Delta, Nigeria. Am Asso Petrol Geol Bull 91:945-958

McRae SG (1972) Glauconitic Earth-Sci Rev 8:397-440

Merki P (1972). Structural geology of the Cenozoic Niger Delta. (ed. T.F.J. Dessauvagie\& A.J. Whiteman), African Geology, Ibadan Univ. Press, 635-646. 
Mode AW, Dim CIP, Ozumba BM (2015) Sequence stratigraphy and depositional environments of Middle-Late Miocene sediments in the eastern part of the Coastal Swamp depobelt, Niger Delta Basin Nigeria. Arab J Geosci 8:9815-9827

Odin GS, Fullagar PD (1988) Geological Significance of the Glaucony Facies. In: Odin GS (ed) Green Marine Clay. Elsevier, Amsterdam, pp 295-332

Ojo OA (1996). Studies on Biozonation and Paleoecology of the Neogene Foraminifera of Central Niger Delta. Unpublished Ph.D Thesis, Obafemi Awolowo University, Ile-Ife, Nigeria: 305p.

Okosun EA, Liebau A (1999) Foraminiferal Biostratigraphy of Eastern Niger Delta. Nigeria. NAPE Bulletin 13(2):136-156

Opeloye SA (2012) Microfossils and Paleoenvironment of the Numanha Shale of the Upper Benue Trough, Northeastern Nigeria. Journal of Mining and Geology 48(2):167-176

Owoyemi AOD (2004) The sequence stratigraphy of Niger Delta feld, ofshore Nigeria. MSc thesis, Texas A\&M University

Owoyemi AO, Willis BJ (2006) Depositional patterns across syndepositional normal faults, Niger delta, Nigeria. J Sediment Res 76:346-363

Ozumba MB (1997) Aspects of CretaceousTertiary Biostratigraphy of Southwestern Nigeria. NAPE Bulletin, Vol. 12 (Issue1): 46-53Petters SW (1982). Central West African Cretaceous-Tertiary Benthic Foraminifera and Stratigraphy: Palaeontographia A 179:1-104

Petters SW (1979) Some Late Tertiary foraminifera from Parabe-1 Well, Western Niger Delta. Revue Espanol Micropaleontologie 11:119-133

Porrenga DH (1967). Clay mineralogy and geochemistry of recent marine sediments in tropical areas. Publicaties Varler Fysich Geografisch Laboratorium van de Universiteit van Amsterdam, 9p.

Posamentier HW, Vail PR (1988). Eustatic controls on clastic depositional sequence and systems tract models, in Wilgus, C.K., Hastings, B.S. C.G. St. C. Kendall and others (Eds.), sea-level changes; An Integrated Approach: Socienty of Economic Paleontologists and Mineralogists, Special Publication. No.42, pp.125-154.

Prince SM (2018) Sedimentary Processes and Sedimentation in the Shallow Offshore. Eastern Niger Delta, Gulf of Guinea, Sedimentation Engineering, Ata Amini, IntechOpen. https://doi.org/ 10.5772/intechopen.74135

Reijers TJA (2011) Stratigraphy and sedimentology of the Niger Delta. Geologos 17(3):133-162. https://doi.org/10.2478/ v10118-011-0008-3

Reijers TJA., Petters SW, \& Nwajide CS., (1997). The Niger Delta Basin. [In:] R.C. Selley (Ed.): African basins. Sedimentary Basins of the World (Elsevier, Am sterdam) 3, 145-168.

Revil A, Grauls D, Brevart O (2002) Mechanical compaction of sand/ clay mixtures. J Geophys Res 107:2293. https://doi.org/10.1029/ 2001JB000318

Rider M H (1986). The Geological Interpretation of Well Logs. Halsted Press, 1st Ed.: New York, NY.
Schlumberger (1985). Log interpretation and applications: Schlumberger Educational Services,"order no:SMP-7017 Houston, Texas, 1985.

Scholle PA, Spearing D (1998) Sandstone Depositional Environments. AAPG Mem 31:115-328

Seiglie GA, Barker MB, Schineidermann N (1982). Biostratigraphy and Paleoenvironment of the Northern Niger Delta and their Significance to Petroleum Geology (Unpublished). Gulf Oil Company Nigeria.

Selley RC (1997). African Sedimentary Basins of the World; Elsevier Science, Amsterdam, pp. 173 - 186

Serra O, Sulpice L (1975). Sedimentological analysis of sand and shale series from well logs. SDWLA 16th Ann Symp. Trans. Paper. WT, pp. 1-24

Shell (2010). Chronostratigraphic scheme-an intermediate update to the current 1998 Niger Delta Cenozoic Chronostratigraphic Chart. Shell Petroleum Development Company UIG-T/DGX Geological Services, Warri

Short KC, StaubleAJ, (1967) Outline geology of the Niger Delta. Am Assoc Petroleum Geolo Gists Bull 51:761-779

Smulikowski K (1954) The Problem of Glauconite Archwm Miner 18:21-109

Stacher P., (1995). Present understanding of the Niger Delta hydrocarbon habitat. [In:] M.N. Oti \& G. Postma (Eds): Geology of deltas. Balkema, Rotterdam, 257-268

Stoneley R (1966) The Niger Delta Region in the light of the Continental Drift. Geol Magazine 103:385-397

Ulasi AI, Onyekuru SO, Iwuagwu CJ (2012) Petrophysical evaluation of Uzek well using log and core data, offshore Depobelt, Niger Delta, Nigeria, Advances in Applied Science Research, Pelagia Research. Library 3(5):2966-2991

Urang JG, Ebong DE, Akpan AE, Akaerue EI (2020) A new approach for porosity and permeability prediction from well logs using artificial neural network and curve fitting techniques: A case study of Niger Delta. Nigeria. Journal of Applied Geophysics 183:104207

Weber KJ (1971) Sedimentological aspects of oil fields in Niger Delta. Geologize En Mingbouw 50:559-576

Weber KJ, Daukoru E (1975). Petroleum geology of the Niger Delta. Proceedings of the Ninth World Proceedings of the Ninth World Petroleum Congress 2, 209. ®222.

Wyllie MRJ, Rose WD (1950) Some theoretical considerations related to the quantitative evaluations of the physical characteristics of rock from electric log data. J Petrol Technol 189:105-110

Publisher's Note Springer Nature remains neutral with regard to jurisdictional claims in published maps and institutional affiliations. 